\title{
Role of Intensive Training in the Growth and Maturation of Artistic Gymnasts
}

\author{
Robert M. Malina - Adam D. G. Baxter-Jones · Neil Armstrong • \\ Gaston P. Beunen • Dennis Caine - Robin M. Daly • Richard D. Lewis • \\ Alan D. Rogol $\cdot$ Keith Russell
}

Published online: 7 June 2013

(C) The Author(s) 2013. This article is published with open access at Springerlink.com

\begin{abstract}
Short stature and later maturation of youth artistic gymnasts are often attributed to the effects of intensive training from a young age. Given limitations of available data, inadequate specification of training, failure to consider other factors affecting growth and maturation, and failure to address epidemiological criteria for causality, it has not been possible thus far to establish cause-effect relationships between training and the growth and maturation of young artistic gymnasts. In response to this ongoing debate, the Scientific Commission of the International Gymnastics Federation (FIG) convened a committee to review the current literature and address four questions: (1) Is there a negative effect of training on attained adult
\end{abstract}

Professor Gaston Beunen passed away prior to publication of this article.

Electronic supplementary material The online version of this article (doi:10.1007/s40279-013-0058-5) contains supplementary material, which is available to authorized users.

R. M. Malina

Department of Kinesiology and Health Education, University of

Texas at Austin, Austin, TX, USA

R. M. Malina

Department of Kinesiology, Tarleton State University,

Stephenville, TX, USA

R. M. Malina $(\bowtie)$

10735 FM 2668, Bay City, TX 77414, USA

e-mail: rmalina@1skyconnect.net

A. D. G. Baxter-Jones · K. Russell

College of Kinesiology, University of Saskatchewan, Saskatoon,

SK, Canada

N. Armstrong

University of Exeter, Exeter, UK stature? (2) Is there a negative effect of training on growth of body segments? (3) Does training attenuate pubertal growth and maturation, specifically, the rate of growth and/ or the timing and tempo of maturation? (4) Does training negatively influence the endocrine system, specifically hormones related to growth and pubertal maturation? The basic information for the review was derived from the active involvement of committee members in research on normal variation and clinical aspects of growth and maturation, and on the growth and maturation of artistic gymnasts and other youth athletes. The committee was thus thoroughly familiar with the literature on growth and maturation in general and of gymnasts and young athletes. Relevant data were more available for females than males. Youth who persisted in the sport were a highly select sample, who tended to be shorter for chronological age but who had appropriate weight-for-height. Data for secondary sex characteristics, skeletal age and age at peak height velocity indicated later maturation, but the maturity status

\section{G. P. Beunen}

Department of Biomedical Kinesiology, Faculty of Kinesiology and Rehabilitation Sciences, Research Center for Exercise and Health, Katholieke Universiteit Leuven, Leuven, Belgium

D. Caine

Department of Kinesiology and Public Health Education, University of North Dakota, Grand Forks, ND, USA

R. M. Daly

Centre for Physical Activity and Nutrition Research, School of Exercise and Nutrition Sciences, Deakin University, Melbourne, VIC, Australia

R. D. Lewis

Department of Foods and Nutrition, University of Georgia, Athens, GA, USA 
of gymnasts overlapped the normal range of variability observed in the general population. Gymnasts as a group demonstrated a pattern of growth and maturation similar to that observed among short-, normal-, late-maturing individuals who were not athletes. Evidence for endocrine changes in gymnasts was inadequate for inferences relative to potential training effects. Allowing for noted limitations, the following conclusions were deemed acceptable: (1) Adult height or near adult height of female and male artistic gymnasts is not compromised by intensive gymnastics training. (2) Gymnastics training does not appear to attenuate growth of upper (sitting height) or lower (legs) body segment lengths. (3) Gymnastics training does not appear to attenuate pubertal growth and maturation, neither rate of growth nor the timing and tempo of the growth spurt. (4) Available data are inadequate to address the issue of intensive gymnastics training and alterations within the endocrine system.

\section{Introduction}

Artistic gymnasts of both sexes are characterized by short stature, later maturation and a slower tempo of growth [13]. Female gymnasts tend to be relatively linear (ectomesomorphic) while males tend to be muscular (mesomorphic) [4], reflecting sex differences in physique [5].

A question that is consistently raised is whether the growth and maturity characteristics observed in gymnasts are a consequence of training, normal physical development or interactions between the two, e.g. accretion and hypertrophy of muscle mass during adolescence and young adulthood in males [5]. The issue has received considerable attention since the 1970s and 1980s when Olga Korbut and Nadia Comaneci achieved success at World Championships (WC) and Olympic Games (OG) with what were perceived as physiques of pre-pubertal 'girls' in contrast to Olympians of the 1950s (Larissa Latynina) and 1960s (Vera Ćáslavská). Mean ages, heights and weights of world class female artistic gymnasts declined from the mid-1960s

\section{R. D. Lewis}

Department of Kinesiology, University of Georgia, Athens, GA, USA

A. D. Rogol

Riley Hospital for Children, Indiana University School of Medicine, Indianapolis, IN, USA

\section{A. D. Rogol}

Department of Pediatrics, University of Virginia, Charlottesville, VA, USA

K. Russell

Scientific Commission of Fédération Internationale de Gymnastique, Lausanne, Switzerland through the 1980s [1, 4]. Minimum age for participants was 13.0 years at the 1987 WC (Rotterdam, The Netherlands) and raised to 16.0 years at the 1997 WC (Lausanne, Switzerland). Mean ages have since increased: 16.5 (1987 WC), 17.4 (1997 WC), 18.0 (2000 OG), and 18.8 (2008 OG) years; however, heights and weights have changed little from $1987(154 \mathrm{~cm}, 45 \mathrm{~kg})$ to $2000(152 \mathrm{~cm}, 43 \mathrm{~kg})$ [6] and $2008(153 \mathrm{~cm}, 45 \mathrm{~kg})$ OG [7].

The short stature and later maturation observed in female artistic gymnasts have often been attributed to the effects of intensive gymnastics training from a young age [8-18]. This perhaps reflects the earlier attainment of advanced levels of training and competition among females, specifically during the interval of the adolescent growth spurt, whereas the more rigorous training for male gymnasts occurs later in the growth spurt when significant gains in muscle mass and muscular strength occur [5]. The size and maturation of male gymnasts have thus not been placed under similar scrutiny, although it has been suggested that their 'growth deterioration' is more marked compared with females [16].

It is not possible, however, to establish cause-effect relationships between training and outcome measures due to limitations of available data, inadequate specification of training, failure to consider other factors affecting growth and maturation, and failure to address epidemiological criteria for causality [2, 3, 19-22].

In response to this ongoing debate, the Scientific Commission of the International Gymnastics Federation (FIG) convened the authors of this paper in 2011 to review the current literature and address four questions on the growth and maturation of artistic gymnasts: (1) Is there a negative effect of training on attained adult stature? (2) Is there a negative effect of training on growth of body segments? (3) Does training function to attenuate pubertal growth and maturation, specifically rate of growth and timing and tempo of maturation? (4) Does training negatively influence the endocrine system? The committee was also asked to address terminology for characterizing the growth and maturation of gymnasts and issues for further study.

The basic information used in the review is derived from the active involvement of committee members selected for their research on normal variation and clinical aspects of growth and maturation, and on the growth and maturation of artistic gymnasts and youth athletes in other sports. As a group, the committee had considerable experience in 'hands-on' research with the physical growth and biological maturation of artistic gymnasts. Several members of the committee were also reasonably well versed in the nonEnglish literature from Germany and Eastern Europe. The committee was thus thoroughly familiar with the literature on growth and maturation in general and relative to gymnasts and young athletes of both sexes. A meta-analysis 
was not performed due to lack of uniformity in the available literature relative to study designs, age ranges and competitive levels of gymnasts, and variables considered.

\section{Gymnastics Training}

Training is routinely described in the scientific literature as hours per week (see Supplemental Table 1 [Online Resource 1]). Studies span 30-40 years, most consider athletes 14 years of age and under, several combine athletes across a broad age range and several include gymnasts at major championships. Average time training reported by gymnasts at major championships was $\sim 30 \mathrm{~h} /$ week, but variation was considerable [16, 17, 23]. Overall, reported weekly time in training overlaps in females and males, and increases with age and level of competition. Weekly training in gymnastics schools of the former Soviet Union increased, for example, from $8 \mathrm{~h} /$ week in initial training at 5-6 years of age to 32-36 h/week for elite training at 16-18 years [24]. Coach-recommended training 'thresholds' for select English gymnasts (Training of Young Athletes [TOYA] study, 1987-1990) [25] increased from 9 to $18 \mathrm{~h} /$ week between 8 and 16 years of age, but were less than the volume of training for youth in the former Soviet Union (Supplemental Table 1 [Online Resource 1]). English girls exceeded the coach-recommended thresholds at 8 $(61 \%)$ and $10(90 \%)$ years of age, but were below thresholds at 12-16 years; boys exceeded thresholds at 8 and 10 years $(\sim 64 \%)$, equaled the threshold at 12 years (50\%), but were below thresholds at 14-16 years [26].

Training regimens evolve over time so that information reported in the literature may not be representative of elite gymnasts today. The 'optimal plan' for training elite US female gymnasts, for example, suggests two daily sessions (morning 2-3 h, afternoon 3-4 h), 6 days per week [27]. Allowing for age (junior pre-elite 11-14 years, junior elite $11-15$ years, senior elite $\geq 16$ years), the 'optimal plan; translates to $30-42 \mathrm{~h} /$ week plus $1 \mathrm{~h}$ of dance training at least twice per week by a dance professional familiar with needs of artistic gymnastics.

Intensity of training, in contrast to time, is more relevant to the questions of interest, but criteria for intensive training are lacking. Estimated energy costs (METs) of gymnastics for youth vary with level of effort: light, 3.0; moderate, 4.0; hard, 5.0 METs [28, 29]. Specific training activities are not ordinarily reported - warm-up, stretching, strength training, instruction and repetition of specific skills and routines, rest between repetitions, dance and choreography, and others, and little attention is given to the differences in the sport for females and males.

Several more specific approaches to document training among young gymnasts have also been used [8, 24, 30-32].
Video and direct observations of classes for girls 4-8 years of age indicated, on average (mean \pm standard deviation), $1.2 \pm 0.6$ and $7.9 \pm 3.1 \mathrm{~h} /$ week, and 63 and $259 \mathrm{~h}$ per year, respectively, in low- and high-level classes [30]. The latter, however, included greater variability and complexity of gymnastics elements.

Practice protocols of select Polish youth gymnasts (four females, 12-14 and four males, 13-15 years of age) were followed for 19 and 22 weeks, respectively, in 1973 (see Supplemental Table 2 [Online Resource 1]) [8]. Allowing for small samples, females had more sessions $(7.6 \pm 1.8 \mathrm{vs}$. $6.0 \pm 1.5)$ and did more repetitions $(3,408 \pm 795$ vs. $2,980 \pm 1,114)$ per week than males, while males trained more hours per week $(30 \pm 8$ vs. $23 \pm 5)$ and at a somewhat greater estimated intensity $(3.6 \pm 0.6$ vs. $3.3 \pm 0.5)$ than females. Intensity was based on a weighted score for the total number of low-, moderate- and high-intensity gymnastic elements per unit time. Adolescent girls had more hours, sessions and repetitions than Polish national team members, but the latter trained at a greater intensity. Weekly repetitions and training intensity of the adolescent boys were higher than estimates for first class youth gymnasts in the former Soviet Union [8]. By comparison, elite and advanced US female youth gymnasts in the 1980s trained $20-27 \mathrm{~h}$ per week through the year [33], while contemporary elite level gymnasts train 20-30 h per week, 45-48 weeks per year (Russell $\mathrm{K}$, unpublished observations).

Gymnastics training is more complex than hours per week or number of repetitions. The program of gymnastics schools in the former Soviet Union illustrates a variety of activities and changing emphasis with increasing age (Supplemental Table 3 [Online Resource 1]) [24]. Time spent in specific activities varies with age and level in gymnastics. Although dating to the 1980s, the programme highlights time distribution and shifting emphases in specific training activities.

Detailed observations of training load and intensity among high level Australian male gymnasts $(10.5 \pm 0.9$ years of age $)$ in the 1990 s provide additional insights. Eight sessions were videotaped during three training phases: routine development (RD), pre-competition (PC), and strength and conditioning (SC). Heart rate was also monitored. Impacts (loads) for the upper and lower extremities were calculated and ground reaction forces for common activities were measured [31, 32]. About $63 \%$ of total training time was devoted to rest or recovery. Work-rest ratios varied among RD 1:1.78; PC 1:1.94, and SC 1:1.44. Mean heart rate was 127.5 beats per minute (bpm), and varied with apparatus and training phase. Transient peak rates ranged from 158 to $184 \mathrm{bpm}$ on the high bar and 171 to $184 \mathrm{bpm}$ on the parallel bars. Mean heart rate was $\sim 60$ to $\sim 65 \%$ of maximal values in children [31]. Mean number of impact loads varied between 102 and 217 per session. Static 
support loading on the hands/wrists averaged 11-16 min, while swinging on bars averaged $4.5 \mathrm{~min}$ per session. Peak vertical ground reaction forces on the upper extremities ranged between 1.5 and 3.6 times body weight; corresponding peak forces on the lower extremities ranged between 3.7 and 10.4 times body weight [32].

\subsection{Summary}

Hours per week provide limited information about demands placed upon young artistic gymnasts. Hours training include considerable 'down time' or reduced activity associated with instruction, waiting between repetitions, recovery, nutrition breaks, etc. Specific emphases and intensities of training vary among individuals, with age and competitive level, during the season, and among coaches. Training loads and sequencing of training activities are highly variable among individuals, which limit comparisons. Variation among individuals in responsiveness to gymnastics training has not been systematically considered. Responsiveness to training is an individual characteristic that has a genotypic component [34].

Differences among studies and individual athletes, seasonal variation and lack of information correlating hours per week with indicators of growth and maturation preclude establishing a threshold of training time within which to evaluate available data. If in fact a training threshold does exist, it is likely to be highly individual. Moreover, information relating training to gymnastics performance is lacking. Involvement in other physical activities also merits consideration. More than one-half of female gymnasts (levels 4-10, USA Gymnastics) reported participation in other sports with little variation by competitive level [35], while mixed-longitudinal samples of female gymnasts and non-gymnasts did not differ in habitual physical activity from 4 to 10 years of age [36].

\section{Early Growth, Parent Size}

It is often stated that athletes are born and made, highlighting the importance of inherited phenotypic characteristics in addition to possible effects of training. For example, birth lengths and weights of female gymnasts do not differ from swimmers and school girls [37-39]. Although recreational and select gymnasts of both sexes are shorter than average before beginning intensive training $[30,36,39,40]$, their heights are, on average, within the normal range. Gymnasts of both sexes also have shorter parents than the general population or athletes in other sports [8, 39-43], but there are exceptions [44]. Given familial aggregation of height $[5,34]$, shortness probably represents a familial characteristic.

\section{Selectivity, Differential Dropout}

Consistent with other sports, artistic gymnastics is very selective. Among level 9 and 10 gymnasts, only 79 of 4,932 women (1.6\%) and 136 of 1,418 men $(9.6 \%)$ were classified elite by USA Gymnastics in 2009 [45].

Select Polish female gymnasts [8] who persisted in the sport $(n=5)$ were, on average, shorter from 12 to 15 years and lighter from 12 to 17 years of age than those who dropped out $(n=4)$. The difference persisted at 17 years of age but was not significant: persist, $17.0 \pm 1.1$ years, $158.2 \pm 2.5 \mathrm{~cm}$; dropout, $17.5 \pm 0.7$ years, $159.2 \pm$ $5.6 \mathrm{~cm}$. Peak height velocity (PHV) and menarche occurred slightly, but not significantly, later in continuing gymnasts compared with dropouts: PHV, $13.3 \pm 1.0$ and $13.1 \pm 0.8$ years $(n=3)$, and menarche, $15.2 \pm 1.2$ and $15.0 \pm 0.4$ years of age, respectively [2, 8]. Polish male gymnasts who persisted $(n=7)$ were, on average, shorter than those who dropped out $(n=8)$ from 12-18 years of age, but differences in weight between groups were not consistent. Height differences continued in late adolescence but were not significant: persist, $18.2 \pm 0.7$ years, $166.0 \pm 4.8 \mathrm{~cm}$; dropout, $17.9 \pm 0.8$ years, $167.9 \pm 3.4$ $\mathrm{cm}$. PHV occurred earlier in dropouts $(14.6 \pm 0.8$ years $)$ than in those who continued (15.2 \pm 0.7 years) $[2,8]$.

Among elite Swiss females gymnasts, dropouts $(n=12)$ were taller, heavier and advanced in skeletal age (SA) at baseline (7-14 years) compared to those who persisted $(\mathrm{n}=12)$, and attained menarche earlier (13.7 vs 14.9 years; variance statistics not reported). Mean heights and weights did not differ significantly at 16-19 years (mean 17.0 years): persist $165.6 \mathrm{~cm}, 55.6 \mathrm{~kg}$; dropout $167.5 \mathrm{~cm}, 56.7 \mathrm{~kg}$ [44]. Dropouts were older and advanced in SA compared with continuing Belgian female gymnasts, but controlling for chronological age (CA), the groups did not differ in anthropometry and items of the European Test of Physical Fitness (EUROFIT) battery [46, 47]. Age also differentiated between Canadian continuing gymnasts and dropouts; the latter were significantly older [48].

Gymnasts of both sexes who persist in the sport through adolescence are as a group shorter and later maturing than those who dropout. The available literature does not permit conclusions whether dropouts were self-selected or selectively excluded. Behavioural factors have been implicated in dropping out, but not specified [48].

\subsection{Summary}

Evidence suggests that gymnasts as a group, though somewhat shorter than average on entering the sport (4-6 years of age), have heights within the normal range. Those who persist in the sport tend to be shorter leading to 
the question of whether elite gymnasts are a self-selected group or are selected by others based on shorter stature.

\section{Growth Status and Adult Stature}

To answer the question of whether adult stature is compromised, three related issues require consideration: (1) When is mature (adult) stature attained? (2) What are the adult heights of short-, late-maturing youth who are not athletes? (3) How accurate are prediction equations for height applied to short youth or short youth with delayed puberty or later SA relative to CA?

The two criteria for defining adult stature in longitudinal studies are (1) four successive 6-monthly increments $<0.5 \mathrm{~cm}$ and (2) an annual increment $<1.0 \mathrm{~cm}$ (Supplemental Table 4 [Online Resource 1]). Median ages at attaining adult stature vary between criteria within sexes. Depending on criterion, some girls attain adult stature as early as 14 years of age, whereas some youth, boys more so than girls, do not attain adult stature until their early $20 \mathrm{~s}$ [49]. With few exceptions, longitudinal studies of gymnasts are typically discontinued by $16-17$ years; hence, it is difficult to ascertain whether or not adult stature has been attained.

Most samples of artistic gymnasts of both sexes present age-group-specific mean heights that track along or below the tenth percentiles of US growth charts and display growth curves, pubertal development and SAs characteristic of later maturation during adolescence $[1,3]$. As such, the growth and pubertal characteristics of short-, latematuring youth who are not athletes merit consideration [50-53]. Four groups were identified. First, short-, normal-, late-maturing youth from the combined samples for six major longitudinal studies in the US were defined as having heights less than the tenth percentiles of the US growth charts for at least two successive examinations between 3 and 18 years of age, SA at least one standard deviation less than CA, and free of disease [50]. Second, late-maturing youth with short parents from the Wrocław Growth Study (Poland) were defined by a difference between SA and CA in the lowest tertile at 12 years of age in girls and 14 years of age in boys in the respective longitudinal samples and a mid-parent height in the lowest tertile for girls and boys, respectively, in the longitudinal samples (Koziel S, personal communication for girl's data) [51]. Third, youth from nine European pediatric clinics with idiopathic short stature that were defined by a height below two standard deviations of population-specific means and absence of detectable causes [52]. Fourth, German youth with short stature and constitutional delay were defined by a height at initial observation below age- and sex-specific third percentiles for West German children, SA 2 or more years later than CA, absence of known causes of short stature, and age at follow-up $>18$ years in girls and $>20$ years in boys [53]. Numbers of youth in the respective samples are indicated subsequently in tables comparing young adult heights and ages at peak height velocity (PHV) with values for artistic gymnasts.

Few longitudinal studies of gymnasts include adult or near adult height. Adult height is often 'predicted' and height attained at or near adulthood is compared with 'predicted mature height'. Commonly used prediction equations require SA: Bayley-Pinneau (BP), TannerWhitehouse mark II (TW mark II) and Roche-WainerThissen (RWT) [5]. Mid-parent target height (MPTH) requires parental heights and has an error of $\pm 10 \mathrm{~cm}$. Accuracy of parental heights is a source of error, while accuracy of prediction equations with short youth is also important. Among short-, normal-, slow-maturing youth, mean prediction errors vary between 2.3 and $-0.8 \mathrm{~cm}$ in girls and 1.7 and $-0.5 \mathrm{~cm}$ in boys [50]. For youth with short stature and constitutional delay, mean errors range from -2.1 to $2.6 \mathrm{~cm}$ in females and -7.1 to $3.1 \mathrm{~cm}$ in males [53].

Late adolescent and young adult heights, and predicted adult heights of female gymnasts are summarized in Table 1 with corresponding data for several samples of short non-athletes. Studies reporting only standard deviation scores were excluded. Mean measured heights (and standard deviations) of active late adolescent/young adult gymnasts and collegiate and retired gymnasts, and mean predicted adult heights of gymnasts overlap considerably. Mean predicted heights of gymnasts with four different protocols (MPTH, BP, TW mark II, RWT) are within the same range [38]. Young adult heights of gymnasts also overlap those of other short females who are not athletes.

Corresponding data for male gymnasts and several samples of short non-athletes are shown in Table 2. Mean measured and predicted adult heights (and standard deviations) of gymnasts overlap, but mean predicted heights are more variable. Late adolescent growth in nine members of the Canadian team should be noted; mean height at 24 years of age was $2.4 \mathrm{~cm}$ greater than at 18 years [54]. Adult heights of male gymnasts overlap those of other short males who are not athletes.

Parent-child similarities in height and inter-generational differences between parents and children should also be noted. Late adolescent heights of eight Polish female gymnasts were strongly correlated with parent heights (mothers, $r=0.52$; fathers, $r=0.41$ ), but those of 14 males were not correlated (fathers, $r=-0.11$; mothers, $r=-0.00^{1}$ ). The situation in Poland at the time of the

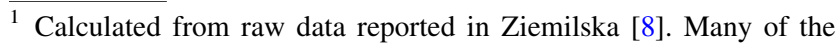
results are reported in Malina [2].
} 
Table 1 Measured and predicted mature (adult) heights of late adolescent and young adult female artistic gymnasts and short female nonathletes

\begin{tabular}{|c|c|c|c|c|c|c|}
\hline Study & Groups & $\begin{array}{l}\text { No. of } \\
\text { subjects }\end{array}$ & $\begin{array}{l}\text { Age } \\
\text { (years) }^{\mathrm{a}}\end{array}$ & $\begin{array}{l}\text { Measured } \\
\text { height }(\mathrm{cm})^{\mathrm{a}}\end{array}$ & $\begin{array}{l}\text { Predicted } \\
\text { height }(\mathrm{cm})^{\mathrm{a}}\end{array}$ & Prediction methods \\
\hline \multicolumn{7}{|l|}{ Gymnasts } \\
\hline \multirow[t]{3}{*}{ Ziemilska [8] } & Polish elite youth & 8 & $17.4 \pm 0.9$ & $158.3 \pm 4.0$ & $\begin{array}{l}161.2 \pm 2.2 \\
159.4 \pm 3.4\end{array}$ & $\begin{array}{l}\text { Prokopec [119] } \\
\text { MPTH }^{\text {b }}\end{array}$ \\
\hline & Polish national team, 1970 & 17 & $18.1 \pm 2.3$ & $159.5 \pm 6.1$ & & \\
\hline & Polish national team, 1978 & 10 & $17.2 \pm 3.2$ & $157.4 \pm 2.2$ & & \\
\hline Caldarone et al. [59] & $\begin{array}{l}\text { European Junior } \\
\text { Championship } 1984\end{array}$ & 52 & $14.0 \pm 0.9$ & & $153.9 \pm 5.3$ & $\begin{array}{l}\text { Mean of BP, RWT, } \\
\text { TW mark II }\end{array}$ \\
\hline Theintz et al. $[12,38]$ & Swiss elite & 22 & & & $\begin{array}{l}159.6 \pm 4.4 \\
160.6 \pm 4.5\end{array}$ & $\begin{array}{l}\text { TW mark II } \\
\text { MPTH }\end{array}$ \\
\hline Tönz et al. [44] & Swiss junior elite & 24 & $16-19$ & $166.3 \pm 5.3$ & & \\
\hline Claessens [120] & World Championship 1987 & $\begin{array}{l}31 \\
10 \\
24\end{array}$ & $\begin{array}{l}17.5 \pm 0.3 \\
18.4 \pm 0.3 \\
20.1 \pm 1.1\end{array}$ & $\begin{array}{l}156.8 \pm 6.2 \\
156.4 \pm 4.9 \\
155.1 \pm 5.8\end{array}$ & & \\
\hline Weimann et al. [69] & German elite & 22 & $13.6 \pm 1.0$ & & $\begin{array}{l}161.5 \pm 3.5 \\
158.0 \pm 6.2\end{array}$ & $\begin{array}{l}\text { MPTH } \\
\text { BP }\end{array}$ \\
\hline Georgopoulos et al. [23] & $\begin{array}{l}\text { World Championship } \\
\text { 1999-2001 }\end{array}$ & 142 & $17.3 \pm 1.9$ & $154.4 \pm 6.6$ & $161.1 \pm 4.7$ & MPTH \\
\hline Malina R, unpublished data & US Junior-Senior National & $\begin{array}{r}11 \\
5\end{array}$ & $\begin{array}{l}17.4 \pm 0.3 \\
19.3 \pm 2.2\end{array}$ & $\begin{array}{l}155.4 \pm 4.5 \\
155.4 \pm 6.4\end{array}$ & & \\
\hline $\begin{array}{l}\text { Official Website of the Beijing } \\
\text { Olympic Games [7] }\end{array}$ & $\begin{array}{l}\text { Beijing Olympic Games } \\
2008^{\mathrm{c}}\end{array}$ & $\begin{array}{l}24 \\
23\end{array}$ & $\begin{array}{l}17.9 \pm 0.6 \\
22.3 \pm 3.2\end{array}$ & $\begin{array}{l}155.0 \pm 7.5 \\
154.8 \pm 7.4\end{array}$ & & \\
\hline Kirchner et al. [121] & US collegiate & 26 & $19.7 \pm 1.0$ & $158.0 \pm 5.6$ & & \\
\hline Bass et al. [66] & Australian elite, retired & 36 & $25.0 \pm 5.4$ & $163.4 \pm 4.8$ & & \\
\hline Pollock et al. [122] & US collegiate, retired & 16 & $36.1 \pm 3.5$ & $162.4 \pm 6.1$ & & \\
\hline Erlandson et al. [42] & English elite, follow-up & 38 & $21-29$ & $162.4 \pm 5.9$ & $162.8 \pm 5.6$ & MPTH \\
\hline Non-Gymnasts & & & & & & \\
\hline Khamis and Roche [50] & $\begin{array}{l}\text { US, short normal, slow } \\
\text { maturing }\end{array}$ & 44 & 18.0 & $158.5 \pm 3.9$ & & \\
\hline $\begin{array}{l}\text { Koziel S, personal } \\
\text { communication }\end{array}$ & $\begin{array}{l}\text { Polish, normal, late } \\
\text { maturing, short parents }\end{array}$ & 31 & & & $155.1 \pm 4.8$ & $\begin{array}{l}\text { Preece-Baines } \\
\text { Model } 1\end{array}$ \\
\hline Brämswig et al. [53] & $\begin{array}{l}\text { German, short stature, } \\
\text { constitutional delay }\end{array}$ & 32 & $21.1 \pm 2.0$ & $157.8 \pm 4.2$ & & \\
\hline
\end{tabular}

$B P$ Bayley-Pinneau, $C A$ chronological age, $M P T H$ midparent target height, $R W T$ Roche-Wainer-Thissen, $S A$ skeletal age, $S D$ standard deviation, TW mark II Tanner-Whitehouse mark II

${ }^{a}$ Data are presented as mean, range and mean \pm SD where stated

${ }^{\mathrm{b}}$ Calculated from individual data reported in Ziemilska [8]

c Calculated in two age groups, 17-18 and 19+ years from heights reported on the official Beijing Olympic Games website [7]. CA were from birth dates reported on the official website as of 8 August 2008

${ }^{\mathrm{d}}$ Height $<10$ th percentiles of US reference data and SA at least one SD less than CA [50]

e Normal, late maturing (SA at CA of 12) with short parents (midparent height)

${ }^{\mathrm{f}}$ Heights less than $2 \mathrm{SD}$ of the reference [53]

study (1970s) requires consideration. Gymnasts were aged 11-12 years at the study's initiation. Assuming their parents were in their 30s, they would have been born before, during and/or shortly after World War II. Heights of fathers of gymnasts $(n=22,168.6 \pm 5.1 \mathrm{~cm})$ and non-athletes $(n=24,169.4 \pm 5.0 \mathrm{~cm})$ were, on average, similar to a national sample of 19-year-old conscripts measured in 1965 (born in 1946, 170.5 $\pm 5.9 \mathrm{~cm}$ ), but shorter than conscripts surveyed in 1975 (born in 1956, $173.2 \pm 6.3 \mathrm{~cm}$ ) [55]. The study was done in Warsaw, 
Table 2 Measured and predicted mature (adult) heights of late adolescent and young adult male artistic gymnasts and short male non-athletes

\begin{tabular}{|c|c|c|c|c|c|c|}
\hline Study & Groups & $\begin{array}{l}\text { No. of } \\
\text { subjects }\end{array}$ & $\begin{array}{l}\text { Age } \\
\text { (years) }^{\mathrm{a}}\end{array}$ & $\begin{array}{l}\text { Measured } \\
\text { height }(\mathrm{cm})^{\mathrm{a}}\end{array}$ & $\begin{array}{l}\text { Predicted } \\
\text { height }(\mathrm{cm})^{\mathrm{a}}\end{array}$ & Prediction methods \\
\hline \multicolumn{7}{|l|}{ Gymnasts } \\
\hline \multirow[t]{3}{*}{ Ziemilska [8] } & Polish elite youth & 14 & $18.0 \pm 0.8$ & $166.8 \pm 4.2$ & \multirow[t]{3}{*}{$\begin{array}{l}171.0 \pm 1.4 \\
170.4 \pm 1.7\end{array}$} & \multirow[t]{3}{*}{$\begin{array}{l}\text { Prokopec [119] } \\
\text { MPTH }^{\text {b }}\end{array}$} \\
\hline & Polish national team, 1970 & 14 & $22.3 \pm 3.9$ & $168.6 \pm 3.4$ & & \\
\hline & Polish national team, 1978 & 11 & $24.6 \pm 3.2$ & $166.8 \pm 5.0$ & & \\
\hline Caldarone et al. [60] & $\begin{array}{l}\text { European junior } \\
\text { championship } 1984\end{array}$ & $\begin{array}{l}47 \\
18 \\
10\end{array}$ & $\begin{array}{l}17.1 \pm 0.9 \\
17 \\
18\end{array}$ & $\begin{array}{l}167.5 \pm 5.2 \\
169.1 \pm 4.0\end{array}$ & $168.1 \pm 5.8$ & $\begin{array}{l}\text { Mean of BP, RWT, } \\
\text { TW mark II }\end{array}$ \\
\hline Faria and Faria [123] & US junior National, Class I & 24 & $16.9 \pm 0.1$ & $171.1 \pm 8.1$ & & \\
\hline $\begin{array}{l}\text { Jancarik and Salmela } \\
\text { [54] }\end{array}$ & $\begin{array}{l}\text { Canada, national team, } \\
\text { longitudinal }\end{array}$ & 9 & $\begin{array}{l}17.8 \\
23.9\end{array}$ & $\begin{array}{l}165.4 \pm 5.1 \\
167.8 \pm 3.5\end{array}$ & & \\
\hline Claessens et al. [112] & World Championship 1987 & 165 & $21.9 \pm 2.4$ & $167.0 \pm 6.3$ & & \\
\hline Markou et al. [17] & $\begin{array}{l}\text { European Championship } \\
2002^{\mathrm{c}}\end{array}$ & 68 & $17.0 \pm 1.0$ & $167.0 \pm 6.0$ & & \\
\hline $\begin{array}{l}\text { Österback and } \\
\text { Viitasalo [124] }\end{array}$ & $\begin{array}{l}\text { Finland, regular participants } \\
\quad(5 \pm 2 \text { years })\end{array}$ & $\begin{array}{r}17 \\
9\end{array}$ & $\begin{array}{l}12.5 \pm 0.7 \\
16.7 \pm 1.2\end{array}$ & & $\begin{array}{l}176.0 \pm 6.1 \\
174.1 \pm 4.4\end{array}$ & $\mathrm{BP}^{\mathrm{c}}$ \\
\hline Baxter-Jones et al. [43] & English elite & & & & $174.8 \pm 4.3$ & $\mathrm{MPTH}^{\mathrm{c}}$ \\
\hline Weimann et al. [69] & German elite & 18 & $12.4 \pm 1.6$ & & $\begin{array}{l}175.1 \pm 6.7 \\
179.0 \pm 9.0\end{array}$ & $\begin{array}{l}\mathrm{MPTH}^{\mathrm{c}} \\
\mathrm{BP}^{\mathrm{c}}\end{array}$ \\
\hline $\begin{array}{l}\text { Irurtia Amigo et al. } \\
\text { [73] }\end{array}$ & $\begin{array}{l}\text { Spanish elite, mixed- } \\
\text { longitudinal }\end{array}$ & 17 & $19.1 \pm 0.3$ & $170.1 \pm 6.21$ & 169.9 & $\begin{array}{l}\text { Preece-Baines } \\
\text { Model } 1\end{array}$ \\
\hline \multicolumn{7}{|l|}{ Non-gymnasts } \\
\hline Khamis and Roche [50] & $\begin{array}{l}\text { US, short normal, slow } \\
\text { maturing }\end{array}$ & 36 & 18.0 & $168.4 \pm 4.3$ & & \\
\hline $\begin{array}{l}\text { Koziel S, personal } \\
\text { communication }\end{array}$ & $\begin{array}{l}\text { Polish, normal, late maturing, } \\
\text { short parents }\end{array}$ & 18 & & & $168.0 \pm 6.2$ & $\begin{array}{l}\text { Preece-Baines } \\
\text { Model } 1\end{array}$ \\
\hline Brämswig et al. [53] & $\begin{array}{l}\text { German, short stature, } \\
\text { constitutional delay }\end{array}$ & 37 & $23.1 \pm 2.0$ & $170.4 \pm 5.4$ & & \\
\hline
\end{tabular}

$B P$ Bayley-Pinneau, $C A$ chronological age, $M P T H$ midparent target height, $R W T$ Roche-Wainer-Thissen, $S A$ skeletal age, $S D$ standard deviation, TW mark II Tanner-Whitehouse mark II

${ }^{a}$ Data are presented as mean and mean \pm SD where stated

b Calculated from individual data reported in Ziemilska [8]

c The sample was limited to gymnasts with SAs $<18$ years, i.e. skeletally mature gymnasts were excluded

${ }^{\mathrm{d}}$ Height $<10$ th percentiles of US reference data and SA at least 1 SD less than CA [50]

e Normal, late maturing youth (SA at a CA of 14 years) with short parents (midparent height) [51]

${ }^{\mathrm{f}}$ Heights less than $2 \mathrm{SD}$ of the reference [53]

Poland; conscripts from large cities were significantly taller than those from towns and rural areas [56].

\subsection{Summary}

Is there a negative effect of intensive gymnastics training on attained adult stature? Available evidence does not support the suggestion that adult height or near adult height of female and male artistic gymnasts is compromised by intensive gymnastics training at young ages or during the pubertal growth spurt. To answer this question definitively, late adolescent growth of gymnasts should be monitored into the early 20 s.

\section{Growth of Body Segments}

Gymnasts of both sexes have been described as selected for short limbs [11, 41], and/or having relatively short legs for height [57] or stunted growth of the legs [11, 12]. Information on growth of body segments among artistic gymnasts is limited and focuses mainly on upper (sitting height) and lower (leg length) segments per se, and sitting height/ 
standing height or sitting height/leg length ratios. Leg (subischial) length is derived as stature minus sitting height, but measurement or estimation of leg length is not always explicitly specified. Information on growth and proportions of upper extremity segments of gymnasts is lacking.

In a short-term mixed-longitudinal study of Swiss female gymnasts, mean leg length increased linearly from SAs of 10-12 years and did not change across SAs 12-16 years, while sitting height increased linearly with SA from 10 to 16 years [12]. Leg length and sitting height of Swiss swimmers, in contrast, increased with SA from 10 to 16 years. The lower sitting height/leg length ratio of gymnasts $(1.054 \pm 0.005)$ compared with swimmers $(1.100 \pm 0.005)$ was attributed to 'marked stunting of leg length growth' with intensive gymnastics training [12]. CA was not considered. Girls with the same SAs but different CAs, or the same CAs and different SAs, differ in proportions (below). Corresponding ratios for Belgian (calculated after Thomis et al. [58]) and US (Malina R, unpublished data) gymnasts $10-16$ years of age were $1.086 \pm 0.005$ and $1.100 \pm 0.010$, respectively, while unusually low ratios were reported for gymnasts at the 1984 European Junior Championship, $0.94 \pm 0.06$ in females $11-15$ years [59], and $0.89 \pm 0.43$ in males $15-17$ years [60].

The sitting height/height ratio is regularly used as an indicator of relative leg length in growth studies [5]. The ratio declines from infancy through childhood, reaches a nadir circa $10-12$ years in girls and 12-14 years in boys, and increases into late adolescence. The nadir corresponds to earlier adolescent growth in the legs and the late increase corresponds to continued growth of the trunk. Mean sitting height/height ratios for four samples of elite female gymnasts overlapped a reference sample of American White youth aged 10-17 years (Table 3), indicating, on average, no differences in proportions.

Variation in maturity status also influences proportions [5]. Late-maturing youth within a CA group tend to have relatively longer legs than early-maturing youth who have relatively shorter legs. A similar trend is apparent among adolescent female gymnasts (Supplemental Table 5 [Online Resource 1]). Within each CA group of gymnasts aged from 14 to 17 years, post-menarcheal, skeletally mature athletes had relatively shorter legs (higher sitting height to height ratios) than pre-menarcheal and postmenarcheal not skeletally mature athletes who had proportionally longer legs [61]. The latter two groups did not consistently differ in relative leg length.

Peak velocity of growth in leg length $(n=10$, $12.1 \pm 1.5$ years, range $10.1-14.2$ ) precedes peak velocity of growth in sitting height $(n=12,13.3 \pm 1.4$ years, range 11.0-14.8) in Belgian female gymnasts [58], as in other longitudinal samples of girls, though, timing varies [5]. Early-, average- and late-maturing English gymnasts differ in height, sitting height and leg length when aligned on CA during puberty, but differences are negligible when plotted relative to estimated age at PHV and as maturity is approached [22].

Growth in height, sitting height and estimated leg length were followed for 6 months to 2 years in 21 Australian female gymnasts, aged 6-16 years, who were selected as pre-pubertal at baseline [62]. The shorter leg lengths and sitting heights of gymnasts compared with non-gymnasts were interpreted as selection for reduced leg length, but reduced growth rate $(\mathrm{cm} /$ month) in sitting height over

Table 3 Sitting height/standing height ratios (\%) in four samples of female artistic gymnasts relative to reference values for American White youth

\begin{tabular}{|c|c|c|c|c|c|c|c|c|c|c|}
\hline \multirow[t]{2}{*}{ Age (years) } & \multicolumn{2}{|c|}{ US NHES Reference ${ }^{\mathrm{a}}$} & \multicolumn{2}{|c|}{$\begin{array}{l}\text { Belgian } \\
\text { gymnasts }\end{array}$} & \multicolumn{2}{|c|}{$\begin{array}{l}\text { US junior and senior } \\
\text { national gymnasts }\end{array}$} & \multicolumn{2}{|c|}{$\begin{array}{l}\text { World Championship } \\
1987 \text { [120] }\end{array}$} & \multicolumn{2}{|c|}{$\begin{array}{l}\text { European Junior } \\
\text { Championship 1984 [59] }\end{array}$} \\
\hline & Mean \pm SD & Median & $\mathrm{n}$ & Mean \pm SD & $\mathrm{n}$ & Mean \pm SD & $\mathrm{n}$ & Mean \pm SD & $\mathrm{n}$ & Mean \pm SD \\
\hline $10+$ & $52.2 \pm 1.3$ & 52.6 & 11 & $52.6 \pm 0.7$ & & & & & & \\
\hline $11+$ & $52.0 \pm 1.9$ & 52.4 & 12 & $51.9 \pm 1.0$ & & & & & & \\
\hline $12+$ & $52.1 \pm 1.3$ & 52.0 & 13 & $51.6 \pm 1.0$ & & & & & & \\
\hline $13+$ & $52.3 \pm 1.3$ & 52.3 & 11 & $51.9 \pm 0.9$ & 8 & $52.4 \pm 1.2$ & 6 & $52.7 \pm 1.7$ & 11 & $51.0 \pm 1.2$ \\
\hline $14+$ & $52.5 \pm 1.3$ & 52.5 & 11 & $51.9 \pm 1.0$ & 6 & $51.3 \pm 1.3$ & 44 & $52.5 \pm 1.6$ & 31 & $50.5 \pm 1.1$ \\
\hline $15+$ & $52.6 \pm 1.3$ & 52.6 & 9 & $52.4 \pm 1.3$ & 11 & $52.6 \pm 1.5$ & 48 & $52.6 \pm 1.3$ & 5 & $52.9 \pm 1.0$ \\
\hline $16+$ & $53.0 \pm 1.3$ & 52.9 & & & 8 & $52.6 \pm 0.9$ & 31 & $53.0 \pm 1.2$ & & \\
\hline $17+$ & $53.0 \pm 1.3$ & 53.0 & & & 11 & $53.1 \pm 0.7$ & 38 & $52.7 \pm 1.1$ & & \\
\hline $18+$ & & & & & & & 10 & $52.6 \pm 1.2$ & & \\
\hline
\end{tabular}

NHES National Health Examination Survey

a Cycles II and III of the US NHES (1963-1965, 1966-1970), reported in Roche and Malina [64]

b Mixed-longitudinal means calculated for the longitudinal series of elite Belgian gymnasts reported in Thomis et al. [58]

c Junior and senior national gymnasts measured in 1999 (Malina R, unpublished data) 
2 years was attributed to gymnastics training. However, estimated velocities for sitting height and leg length in gymnasts overlapped corresponding estimates for nongymnasts except for a later peak in sitting height [62]. Among four gymnasts who retired at age 11-12 years, estimated monthly sitting height velocities accelerated markedly and were interpreted as catch-up growth with cessation of training [62]. Growth rates of retired gymnasts were within the range of peak velocities of sitting height for 12 Belgian gymnasts, 0.20 to $0.46 \mathrm{~cm} /$ month (converted from $\mathrm{cm} /$ year) [58]. Monthly sitting height velocities decelerated in four of five gymnasts who retired at $\geq 14$ years of age, consistent with continued slow growth into late adolescence. Although growth appeared attenuated during adolescence in gymnasts, it was consistent with a later growth spurt. Moreover, adult proportions did not appear to be compromised.

Corresponding data for male gymnasts are limited. Observations at 3-month intervals over 18 months indicated no differences in estimated monthly growth rates for height, sitting height and leg length between 18 pre- and early-pubertal male gymnasts (baseline, $10.0 \pm 0.8$ years) and age-matched controls (baseline, $9.1 \pm 1.2$ years). $\mathrm{Z}$-scores contrasting sitting height and leg length, humerus and radius lengths, and femur and tibia lengths also did not differ [63]. By inference, gymnastics training over 18 months had no influence on proportional growth in young male gymnasts. The sitting height/height ratio $(51.2 \pm 1.2)$ of male gymnasts (1984 European Junior championship, aged $17.1 \pm 0.9$ years) [60] was slightly lower than reference medians for American White boys aged 16 (51.9) and 17 (52.0) years [64], but the standard deviations overlapped considerably.

\subsection{Summary}

Is there a negative effect of intensive gymnastics training on growth of body segments? Although attenuated growth of upper body (sitting height) and lower body (leg length) segment lengths of gymnasts has been described, it is not possible to link the observations with training. Variation in methodology (due in part to incomplete description) and in $\mathrm{CA}$ and adolescent maturation among individuals confound observations in short-term longitudinal studies. Sitting height/standing height ratios in several samples of elite artistic gymnasts overlap reference values for youth suggesting no differences in relative leg length.

\section{Pubertal Growth and Maturation}

SA is the only maturity indicator that spans childhood and adolescence. Landmarks of the adolescent height velocity curve and secondary sex characteristics are limited to the pubertal years.

\subsection{Skeletal Age}

SAs of gymnasts have been reviewed [1,65]. Some studies selected prepubertal gymnasts and excluded pubertal gymnasts [62, 66]. Allowing for small sample sizes in some studies, mean SAs and CAs were about equal in female gymnasts 5-10 years. With increasing CA during adolescence, SAs lagged behind CAs in most samples, but standard deviations were quite large. The lag in SA relative to CA was greatest in later adolescence. By inference, female gymnasts late and on time (average) in skeletal maturation were predominant while early-maturing gymnasts were a minority. Although not always reported, significant numbers of gymnasts 15-18 years of age were skeletally mature [65].

Corresponding data for males are less extensive. Mean SAs and CAs were similar in childhood, while SAs lagged behind CAs during adolescence in most $[1,10,15,17,65$, 67-69], but not in all samples [60]. In late adolescence, data were equivocal as many male gymnasts $16-18$ years were skeletally mature.

\subsection{Adolescent Growth Spurt}

Estimated ages at peak height velocity (PHV, years) and peak velocities (cm/year) in female artistic gymnasts and short non-athletes are summarized in Table 4. Longitudinal height records of individual gymnasts were mathematically fitted in two studies, but the fit was unsuccessful in three girls. Peak velocity apparently occurred at/near initial observations for two gymnasts (11.5 years [8] and 10.8 years [58]), and between final observations (last measurement 15.1 years) for one gymnast [58]. Ages at PHV were estimated with Preece-Baines Growth Model I (PBGM) applied to cross-sectional mean heights of US gymnasts [21], but this application has limitations with females: “...estimates of the biological parameters were consistently and significantly different from those determined by the longitudinal records... (and)... application of the PBGM to cross-sectional data on females produces invalid results." (p. 569) [70]. Predicted ages at PHV (maturity offset protocol) [71] were used in another study [72].

Allowing for sampling variation and estimation procedures, ages at PHV and peak velocities in female gymnasts overlap those for short- and late-maturing girls who are not athletes. Variation in ages at PHV, 10.55-14.52 years, and peak velocities, $4.58-9.23 \mathrm{~cm} /$ year, among individual gymnasts should be noted. Ages at PHV and peak velocities overlapped those for 31 late-maturing girls with short 
Table 4 Estimates of age at peak height velocity and peak velocity in samples of female artistic gymnasts and short female non-athletes

\begin{tabular}{|c|c|c|}
\hline Group, n, method, reference & 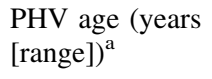 & $\begin{array}{l}\mathrm{PV}(\mathrm{cm} / \text { year } \\
{[\text { range] })^{\mathrm{a}}}\end{array}$ \\
\hline \multicolumn{3}{|l|}{ Gymnasts } \\
\hline $\begin{array}{l}\text { Polish elite, nine followed longitudinally from } 10-12 \text { years for } 5-6 \text { years, [8] individual height data } \\
\text { were successfully modeled in eight gymnasts; graphic interpolation, [8] }\end{array}$ & $\begin{array}{l}13.3 \pm 1.0 \\
{[12.00-14.50]}\end{array}$ & $\begin{array}{l}5.8 \pm 0.5 \\
{[4.65-6.20]}\end{array}$ \\
\hline - Polynomials fitted to longitudinal height records for eight individuals [2] & $\begin{array}{l}13.2 \pm 0.7 \\
{[12.00-14.25]}\end{array}$ & $\begin{array}{l}5.7 \pm 0.5 \\
\quad[4.60-6.10]\end{array}$ \\
\hline $\begin{array}{l}\text { - Kernel regression fitted to longitudinal height records for eight individuals (courtesy of G. Beunen } \\
\text { and M. Thomis) }\end{array}$ & $\begin{array}{l}13.2 \pm 0.9 \\
{[11.97-14.50]}\end{array}$ & $\begin{array}{l}5.7 \pm 0.6 \\
{[4.58-6.22]}\end{array}$ \\
\hline $\begin{array}{l}\text { Belgian regional, national, } 15 \text { followed longitudinally from } 8.7 \pm 1.5 \text { years for } 6-7 \text { years, individual } \\
\text { height data successfully fitted with Preece Baines Model I in } 13 \text { [58] }\end{array}$ & $\begin{array}{l}12.9 \pm 1.5 \\
{[10.55-14.52]}\end{array}$ & $\begin{array}{l}6.8 \pm 1.1 \\
{[4.81-9.23]}\end{array}$ \\
\hline Swiss $(n=22)$, mixed-longitudinal, $2.0-3.7$ years, CA with maximum velocity [12] & 13.0 & 5.5 \\
\hline English, club, regional $(n=45)$, age at PHV estimated with maturity offset protocol [72] & $13.0 \pm 0.7$ & \\
\hline \multicolumn{3}{|l|}{$\begin{array}{l}\text { US }(n=137) \text {, longitudinal } 6 \text { months to } 2 \text { years, Preece-Baines Model I fitted to mixed-longitudinal } \\
\text { mean heights [21] }\end{array}$} \\
\hline - Advanced $(n=72)$ & 13.0 & 6.2 \\
\hline - Intermediate $(n=65)$ & 13.5 & 6.4 \\
\hline \multicolumn{3}{|l|}{ Non-gymnasts } \\
\hline $\begin{array}{l}\text { US, short normal, slow maturing, } 27 \text { from several longitudinal studies [50], kernel regression fitted to } \\
\text { longitudinal height data for individuals }\end{array}$ & $12.4 \pm 1.0$ & $\begin{array}{l}6.9 \pm 1.0 \\
{[5.31-9.10]^{\mathrm{b}}}\end{array}$ \\
\hline $\begin{array}{l}\text { Polish, normal, late maturing with short parents }(n=31) \text { from Wrocław Growth Study, Preece Baines } \\
\text { Model I fitted to longitudinal height data for individuals (Koziel S, personal communication) }\end{array}$ & $\begin{array}{l}12.8 \pm 0.7 \\
{[11.05-14.82]}\end{array}$ & $\begin{array}{l}7.1 \pm 1.0 \\
{[5.59-9.21]}\end{array}$ \\
\hline $\begin{array}{l}\text { Several European countries, idiopathic short stature }(n=84) \text {, mixed-longitudinal [52], fitted with LMS } \\
\text { age at PHV and PHV estimated by visual inspection }\end{array}$ & 13.0 & 5.8 \\
\hline
\end{tabular}

PHV peak height velocity

${ }^{\text {a }}$ Data are presented as mean, range and mean \pm SD where stated

b Range provided by H. Khamis (personal communication)

${ }^{c}$ LMS is a method for fitting and summarizing growth data. It involves three curves: L (lambda) which normalizes height velocity data, M (mu) which corresponds to the median, and S (sigma) which corresponds to the coefficient of variation [52]

parents, $11.05-14.82$ years and $5.59-9.21 \mathrm{~cm}$ per year, respectively. Corresponding peak velocities for 27 normal short-, late-maturing girls ranged from 5.31 to $9.10 \mathrm{~cm} /$ year (Table 4).

Data for males are limited to the longitudinal study of Polish [8] and a mixed-longitudinal study of Spanish [73] gymnasts (Table 5). Height records of two Polish gymnasts could not be fitted. PHV apparently occurred before or shortly after the first observation in one, while heights showed no inflection between initial (14 years) and final (19 years) measurements in the other. Ages at PHV and peak velocities for gymnasts are comparable to non-athlete short males. Ages at PHV for individual gymnasts ranged from 13.41 to 16.70 years and peak velocities from 5.65 to $9.90 \mathrm{~cm} /$ year. The data for gymnasts overlapped those for 18 late-maturing boys with short parents, 13.94 to 15.94 years and 4.91 to $10.43 \mathrm{~cm} /$ year, respectively, while peak velocities for 20 short normal, latematuring boys ranged from 4.62 to $9.47 \mathrm{~cm} /$ year (Table 5).

Available data focus on ages at PHV and peak velocity of growth. Data are not available for age and height at onset (take-off) of the growth spurt, the interval between age at take-off and age at PHV, height at PHV, and growth in height from onset to PHV and from PHV to young adult height in gymnasts of both sexes. Such information would provide more detailed insights into the adolescent spurt of gymnasts. Short-, normal-, slow-maturing boys and girls, for example, started their growth spurts later, were growing at a slower rate at onset of the spurt, were shorter at onset and at PHV, and gained less in height between PHV and 18 years than average boys and girls, respectively; the groups did not differ in growth in height between onset of the spurt and PHV [50]. Nevertheless, the shape of the estimated velocity curve for height, ages at PHV and peak velocities of growth for artistic gymnasts of both sexes are similar to corresponding data for normal-, short-, latematuring youth who are not athletes. Of the available longitudinal data for gymnasts, ages at first observations in some were too late and ages at last observations in others were too early so that parameters of the growth spurt could not be estimated. This highlights the need to monitor the growth of gymnasts from childhood through adolescence and into young adulthood. 
Table 5 Estimates of age at peak height velocity and peak velocity in samples of male artistic gymnasts and short male non-athletes

\begin{tabular}{|c|c|c|}
\hline Group, n, method, reference & $\begin{array}{l}\text { PHV age (years } \\
\text { [range] })^{\mathrm{a}}\end{array}$ & $\begin{array}{l}\mathrm{PV}(\mathrm{cm} / \text { year } \\
[\text { range }])^{\mathrm{a}}\end{array}$ \\
\hline \multicolumn{3}{|l|}{ Gymnasts } \\
\hline $\begin{array}{l}\text { Polish elite, } 14 \text { followed longitudinally from } 10-12 \text { years for } 4-7 \text { years [8], individual height data were } \\
\text { successfully modelled in } 12 \text { of the gymnasts; graphic interpolation [8] }\end{array}$ & $\begin{array}{l}15.1 \pm 0.8 \\
{[13.75-16.50]}\end{array}$ & $\begin{array}{l}7.8 \pm 1.1 \\
{[5.70-9.90]}\end{array}$ \\
\hline - Polynomials fitted to individual longitudinal height records [2] & $\begin{array}{l}15.0 \pm 0.8 \\
{[13.80-16.70]}\end{array}$ & $\begin{array}{l}7.5 \pm 1.1 \\
{[5.75-9.50]}\end{array}$ \\
\hline $\begin{array}{l}\text { - Kernel regression fitted to individual longitudinal height records (courtesy of G. Beunen and M. } \\
\text { Thomis) }\end{array}$ & $\begin{array}{l}14.8 \pm 0.8 \\
{[13.41-16.60]}\end{array}$ & $\begin{array}{l}7.5 \pm 1.1 \\
\quad(5.66-9.61)\end{array}$ \\
\hline Spanish elite, 87 mixed-longitudinal, 219 cross-sectional [72] & 15.0 & 5.8 \\
\hline \multicolumn{3}{|l|}{ Non-gymnasts } \\
\hline $\begin{array}{l}\text { US, short normal, slow maturing, } 20 \text { from several longitudinal studies [50], Kernel regression fitted to } \\
\text { individual longitudinal height records }\end{array}$ & $14.5 \pm 0.9$ & $\begin{array}{l}7.8 \pm 1.1 \\
{[4.62-9.47]^{\mathrm{b}}}\end{array}$ \\
\hline $\begin{array}{l}\text { Polish, normal, late maturing with short parents, } 18 \text { from Wrocław Growth Study [51], Preece Baines } \\
\text { Model I fitted to individual longitudinal height records }\end{array}$ & $\begin{array}{l}14.7 \pm 0.7 \\
{[13.94-15.94]^{\mathrm{c}}}\end{array}$ & $\begin{array}{l}7.9 \pm 1.6 \\
{[4.91-10.43]^{\mathrm{c}}}\end{array}$ \\
\hline $\begin{array}{l}\text { Several European countries, idiopathic short stature, } 145 \text {, mixed-longitudinal data, fitted with } \text { LMS }^{\mathrm{d}} \text {, } \\
\text { age at PHV and PHV estimated by visual inspection [52] }\end{array}$ & 15.0 & 6.7 \\
\hline
\end{tabular}

$P H V$ peak, height, velocity

${ }^{a}$ Data are presented as mean, range and mean \pm SD where stated

${ }^{\mathrm{b}}$ Range provided by Khamis H, personal communication

${ }^{c}$ Ranges provided by Koziel S, personal communication

${ }^{\mathrm{d}}$ LMS is a method for fitting and summarizing growth data. It involves three curves: L (lambda) which normalizes height velocity data, M (mu) which corresponds to the median, and S (sigma) which corresponds to the coefficient of variation [52]

\subsection{Secondary Sex Characteristics}

Indicators include breast (B), genital (G) and pubic hair (PH) development ordinarily assessed on a five-stage scale $(1=$ no development, $2=$ initial appearance, $\quad \ldots$ $5=$ mature state) at clinical examination [74]; selfassessments are also used. Testicular volume and age at menarche are additional indicators. Overt manifestation of B2 and G2 development, on average, mark the transition into puberty in girls and boys, respectively. However, $\mathrm{PH} 2$ may precede B2 and G2 in some youth.

Pubertal stages have major limitations. First, they are discrete categories imposed on a continuous process of maturation. A youngster is either in a stage or not in a stage; there are no intermediate stages. Second, assessments indicate stage at observation; they provide no information on age at entry or duration of the stage. Third, stages are not equivalent within sex $(\mathrm{B} \neq \mathrm{PH} ; \mathrm{G} \neq \mathrm{PH})$ or between sexes $(B \neq G)$. Fourth, duration of a stage and age at transition from one to another are difficult to estimate. Rate of transition through stages to maturity is highly variable and not extensively documented [5].

Sampling and methods of reporting pubertal characteristics of gymnasts vary, which limits comparisons. Some studies simply noted pubertal status was assessed without specifying the characteristic [13]. Others combined B and $\mathrm{PH}$ or $\mathrm{G}$ and $\mathrm{PH}$ into a single score [8, 57], indicated status as $1+, 3+$, etc. $[8,9]$, or reported mean ages of gymnasts in specific stages of $\mathrm{PH}, \mathrm{B}$ or G [16]. Gymnasts were also grouped by pubertal status independent of CA, e.g. prepubertal and peri-pubertal female gymnasts 5-15 years of age [62]. This is problematic, as older girls in the same stage of puberty had several additional years of linear growth compared with the younger girls.

Some short-term studies selected only pre-pubertal gymnasts across a broad age range at baseline (one was in B2 'peri-pubertal') [62, 66]. At initial observation, about $80 \%$ of 15 Swiss female gymnasts aged 12-14 years were pre-pubertal or in early puberty, in contrast to $<20 \%$ of non-athletes $(n=14)$ and swimmers $(n=14)$ of the same age [38]. About $60 \%$ of 27 Swedish female gymnasts 11-14 years of age were also pre-pubertal or in early puberty [13].

The prospective TOYA study noted no differences among gymnasts, swimmers and tennis players in ages at attaining $\mathrm{B} 2$, B3 and $\mathrm{B} 4$, and $\mathrm{PH} 2, \mathrm{PH} 3$ and $\mathrm{PH} 4$; gymnasts attained B5 and PH5 later [42]. When aligned on age at menarche (indicator of biological age), the difference in PH5 was no longer evident. Polish girls active in club-level swimming, athletics and rowing $(n=23)$, did not differ from girls not active in sport $(n=26)$ in estimated ages at attaining B3, B4 and B5 and at PH3, PH4 and PH5, and estimated intervals between stages [75].

The TOYA study noted later attainment of G2, G3 and G4 among male gymnasts compared with athletes in swimming, tennis and soccer. Testicular volume did not 
differ among the athletes in the different sports at ages 9-13 years and at age 19 years, but was less among gymnasts aged 14-17 years [43]. Age-matched male gymnasts (13.3 \pm 0.3 years) and controls $(13.5 \pm 0.3$ years) did not differ in self-assessed G and PH [76].

\subsection{Menarche}

Ages at menarche for individuals can be obtained prospectively or retrospectively [5]. Prospective data are derived from girls followed from pre-puberty through puberty. Retrospective (recall) data have error associated with memory and are affected by the tendency to report ages as whole years. The method has limited utility with youth because some have not attained menarche, which biases sample estimates. Retrospective data for gymnasts were thus not considered.

Age at menarche for a sample can be estimated with the status quo method [5], which requires a relatively large sample spanning 9-17 years of age and two pieces of information for each girl: decimal age and whether or not menarche has occurred (yes/no). Median age at menarche and associated variance statistics are derived with probit or logit analysis.

Only prospective and status quo data deal with youth gymnasts. Prospective samples are generally limited to girls who persist in the sport (see discussion of dropouts), while status quo samples include girls with a wide range of skill at younger ages but more select athletes at older ages. Allowing for the limitations, menarche occurs later in adolescent gymnasts (Supplemental Table 6 [Online Resource 1]). Except for the small sample of Polish gymnasts (15.1 years), means ages at menarche in four other prospective studies range from 14.3 to 14.5 years with standard deviations $0.9-1.4$ years. Two status quo estimates are 15.0 and 15.6 years; the sample for the latter did not include gymnasts less than 13 years of age. The data for gymnasts are generally consistent with short-, latematuring girls who are not athletes. Mean age at menarche for 31 normal-, late-maturing Polish girls with short parents followed longitudinally in the Wroclaw Growth Study was $14.1 \pm 0.9$ years with a range of $12.4-16.3$ years (Kożiel $\mathrm{S}$, personal communication).

Age at menarche shows familial aggregation [5]. The mother-daughter correlation in collegiate athletes (swimming, diving, tennis, golf, athletics, basketball, volleyball) was 0.25 and similar to correlations for ballet dancers and the general population [77]. Correlations for athletes and mothers who were athletes and not athletes were, respectively, 0.24 and 0.22 . Correlations for artistic gymnasts are limited to English gymnasts and their mothers, 0.20 [78], and Polish gymnasts and their mothers, 0.66 (see Footnote 1). Familial correlations reflect genetic co-variation and environmental similarity. Parents and offspring share only one-half of their genes in common and the expected correlation between first degree relatives is 0.50 [34]. The high correlation for nine Polish gymnasts and their mothers suggests a common environmental effect.

\subsection{Summary}

Does intensive gymnastics training attenuate pubertal growth and maturation, specifically rate of growth and timing and tempo of maturation? SA, secondary sex characteristics and landmarks of the growth spurt in female and male artistic gymnasts indicate later maturation. Stature and maturation of gymnasts are similar to short latematuring youth who are not athletes. Allowing for normal variability, gymnastics training does not appear to attenuate pubertal growth and maturation. A primary role for constitutional factors underlying growth (shorter stature) and maturity status (later maturation) of young artistic gymnasts is indicated.

\section{Endocrine Changes}

Training in conjunction with inadequate energy intake has been suggested as exerting an inhibitory effect on the hypothalamic-pituitary-gonadal axis in female artistic gymnasts [11, 12, 79]. Emphasis is on pubertal maturation and specifically age at menarche. However, the role of training and energy balance in timing of menarche in maturing athletes is not clear. Evidence from an experimental exercise programme with post-menarcheal females indicated greater sensitivity of luteinizing hormone (LH) pulsatility to energy deficits in late adolescence than in gynaecologically older women [80]. Disruption of LH pulsatility was also associated with an extreme threshold of negative energy balance in regularly menstruating adults [81]. Corresponding data for maturing girls and athletes are presently not available.

Previous studies reporting gonadal hormone and gonadotropin levels require re-evaluation given assay procedures and timing of samples. Although accurately reported, assays at the time did not measure what authors thought was being measured. Androstenedione and dehydroepiandrosterone sulfate (DHEAS) were likely accurate, but other hormones may not be, given current technologies $[82,83]$. This requires consideration in evaluating earlier studies.

Pre-pubertal female gymnasts and swimmers did not differ in 17- $\beta$-estradiol, DHEAS, LH and follicle stimulating hormone (FSH), but gymnasts had lower levels of estrone, testosterone and androstenedione; in contrast, levels of the six hormones did not differ in early pubertal (B2) gymnasts and swimmers [84]. Compared with early 
pubertal lean girls and small girls $(n=12)$ of the same age, gymnasts had lower LH, 17- $\beta$-estradiol and testosterone, and higher $\mathrm{FSH}$; there were no differences in estrone and androstenedione [85]. Concentrations of estradiol and LH in morning urine samples in a mixedlongitudinal sample of female gymnasts, though lower on average, overlapped the reference from 9-13 years and then showed increases consistent with later sexual maturation [44].

Serum insulin-like growth factor-1 (IGF-1) concentrations were low for CA in select, intensively trained female gymnasts aged 11-17 years, but were within normal ranges relative to SA, 8-15 years [11]. IGF-1 levels declined compared with basal values in pre-pubertal gymnasts $11.5 \pm 0.6$ years during 2 days of intensive apparatus training $(\sim 5 \mathrm{~h} /$ day $)$ with a day of athletics training $(\sim 3.5 \mathrm{~h})$ in between [11]. IGF-1 was also lower in female gymnasts compared with controls and was significantly correlated with SA and height [62].

Elevated cortisol, low T-3 and the anti-insulin action of elevated growth hormone $(\mathrm{GH})$ were suggested as mechanisms contributing to reduced growth in female gymnasts, but the athletes were maintained on a negative energy balance diet [11]. Chronic undernutrition is associated with elevated GH and reduced IGF-1 [86]. Reduced IGF-1 indicates a degree of GH insensitivity.

Data for male gymnasts are limited. Concentrations of testosterone [76] and cortisol and IGF-1 [63] did not differ between gymnasts and age-matched controls. Periods of intensive training were associated with a reduction in the ratio of IGF-1 to cortisol, which was interpreted as a catabolic state due to overtraining, insufficient recovery and/ or inadequate caloric intake relative to energy expenditure [31].

Leptin concentrations have been related to fatness in small samples of gymnasts of both sexes [87]. Levels were low, perhaps reflecting low fat mass in gymnasts. Leptin was related to stage of puberty but CA was not controlled.

\subsection{Summary}

Does intensive gymnastics training have a negative influence on the endocrine system? Presently available data are inadequate to address endocrine changes associated with intensive training in artistic gymnasts.

\section{Nutritional Status, Weight-for-Height}

In addition to altered function of the hypothalamic-pituitary-gonadal axis [11, 12, 79], low body weight and later sexual maturation of female artistic gymnasts have been attributed to excessive energy expenditure and/or insufficient energy intake [16]. Allegations of dietary monitoring and manipulation [88-92], and increased risk of disordered and pathological eating behaviours [92, 93] among elite adolescent female gymnasts are related concerns.

Negative energy balances have been noted, on average, in female gymnasts 6-7 [94], 13-16 [95] and $15.2 \pm 1.8$ [96] years of age. Lower than recommended energy intakes in female gymnasts have also been noted [19]. Allowing for study designs (short term, cross sectional) and limitations of intake estimates, it is difficult to correlate energy intakes/imbalances with height, weight and maturation of gymnasts. Nevertheless, energy intake (3-day record) was an independent predictor of height velocity $\left(R^{2}=0.16\right)$ in a short-term study of pre-pubertal female gymnasts [62].

On average, female gymnasts have lower weights than reference data, but weights are appropriate for their shorter heights [1-3]. It is possible, nevertheless, that some gymnasts present low weight-for-height. Age- and sex-specific criteria for classifying low weight-for-height (thinness) as mild, moderate or severe based on the body mass index (BMI, $\mathrm{kg} / \mathrm{m}^{2}$ ) [97] were applied to data to several samples of female gymnasts (Table 6). Of relevance, BMI is more closely associated with lean rather than fat mass among relatively thin youth [98].

Severe thinness was absent in artistic gymnasts, while mild and moderate thinness occurred most often among world class gymnasts-Rotterdam WC, Beijing OG. Four of six athletes with moderate thinness were Chinese whose ages had been questioned [99-101]. Four US junior-senior gymnasts with mild thinness, and 30 of 41 gymnasts aged $<18.0$ years at the $1987 \mathrm{WC}$ with mild or moderate thinness were pre-menarcheal. With different criteria (BMI less than fifth percentiles, 1977 US charts), six of 137 female gymnasts presented low weight-for-height [21].

\subsection{Summary}

Data on energy intakes/imbalances among female gymnasts are largely short term so that it is difficult to make inferences about the potential influence of high-energy expenditure and low-energy intake on growth in height and weight and maturation; although shorter and lighter, female gymnasts have, on average, appropriate weight-for-height, but maturity status is a factor that affects weight-for-height relationships. Corresponding data for male gymnasts are lacking.

\section{Standard Nomenclature}

Care in using terminology implying a causative link between gymnastics training and growth and maturation is 
Table 6 Estimated thinness of female artistic gymnasts based on the body mass index

\begin{tabular}{|c|c|c|c|c|c|}
\hline \multirow[t]{2}{*}{ Sample } & \multirow[t]{2}{*}{ Age $(\text { years })^{\mathrm{a}}$} & \multirow[t]{2}{*}{ No. of subjects } & \multicolumn{3}{|c|}{ Grades of thinness $^{\mathrm{b}}$} \\
\hline & & & I (mild) & II (moderate) & III (severe) \\
\hline \multirow[t]{3}{*}{ US beginners $\sim 2000[30]^{\mathrm{c}}$} & $4-8$ & 35 & 1 & 0 & 0 \\
\hline & $5-9$ & 35 & 2 & 0 & 0 \\
\hline & $6-10$ & 35 & 1 & 0 & 0 \\
\hline US Junior-Senior National & $12-14$ & 14 & 2 & 0 & 0 \\
\hline \multirow[t]{2}{*}{1999 (Malina R, unpublished data) } & $15-17$ & 30 & 2 & 0 & 0 \\
\hline & $18-19$ & 4 & 0 & 0 & 0 \\
\hline \multirow[t]{2}{*}{ Belgian, national, early $1980 \mathrm{~s},[125]^{\mathrm{c}}$} & $13-14$ & 7 & 1 & 0 & 0 \\
\hline & 16 & 7 & 1 & 0 & 0 \\
\hline \multirow[t]{2}{*}{ Montreal Olympic Games 1976, [126] } & $14-18$ & 11 & 1 & 0 & 0 \\
\hline & $19-20$ & 4 & 0 & 0 & 0 \\
\hline \multirow[t]{4}{*}{ Rotterdam World Championship 1987, $[112,120]^{\mathrm{c}}$} & $13-14$ & 50 & 13 & 1 & 0 \\
\hline & $15-16$ & 79 & 18 & 2 & 0 \\
\hline & $17-18$ & 48 & 8 & 2 & 0 \\
\hline & $\geq 19$ & 24 & 2 & 1 & 0 \\
\hline \multirow[t]{4}{*}{ Beijing Olympic Games 2008 [7] ${ }^{\mathrm{d}}$} & $15-16$ & 24 & 10 & 5 & 0 \\
\hline & $17-18$ & 24 & 10 & 1 & 0 \\
\hline & $19-20$ & 12 & 3 & 0 & 0 \\
\hline & $>20$ & 11 & 2 & 0 & 0 \\
\hline
\end{tabular}

$B M I$ body mass index

${ }^{a}$ Ages are presented in ranges or single years where stated

b Age- and sex-specific cut-off points for grades of thinness were based on mathematically fitted curves (technically, retrofitted) to pooled BMI data from six samples so that they passed through adult criteria for mild (BMI 17.0-18.49 $\mathrm{kg} / \mathrm{m}^{2}$ ), moderate (BMI $\left.16.0-16.99 \mathrm{~kg} / \mathrm{m}^{2}\right)$ and severe $\left(\mathrm{BMI}<16.0 \mathrm{~kg} / \mathrm{m}^{2}\right)$ thinness at 18 years of age [97, 127]

c BMIs of individual gymnasts were calculated by Robert Malina using raw data available to him and raw data provided by Richard Lewis, Gaston Beunen and Albrecht Claessens

${ }^{\mathrm{d}}$ BMIs of participants were calculated from heights, weights and birth dates reported on the official website [7]. Ages were calculated as of the start date of the Games, 8 August 2008

warranted. Examples include adversely affected, blunted growth, growth faltering, without a normal growth spurt, inhibited growth, attenuated growth, deterioration in growth, growth deficits, among others. Data suggesting negative inferences include one longitudinal study spanning adolescence [8], three short-term longitudinal studies with relatively broad baseline age ranges [12, 21, 62], and several cross-sectional studies [10, 13, 15-17].

Growth velocities for height were used in several studies of female gymnasts. Two measurements are required, each with an error component. Measurement error is not ordinarily reported. Since all individuals are typically not measured at precisely 6 month or annual intervals, velocity estimates should be adjusted for the interval between observations for each individual. Diurnal and seasonal variation are additional factors in short-term studies [5, 102]. Height and especially sitting height show significant diurnal variation. Measurements taken shortly after a workout are problematic given the influence of repeated landing impacts on sitting height.
Reported height increments of most gymnasts are within the reference range [12, 62]. Later growth spurts place several outside the range, but adjusting for differential timing shifts increments within the expected reference range. Nevertheless, some gymnasts may show reduced height increments, but it is difficult to attribute them to training given the available data.

Among 59 pre- and peri-pubertal female gymnasts followed for at least 12 months, 21 had height increments $<4.5 \mathrm{~cm} /$ year and were labelled "growth faltering" [21]. The criterion was adapted from a 1-year longitudinal study of children aged 6-12 years in which increments $<5 \mathrm{~cm} /$ year were labelled abnormal [103]. Increments of gymnasts with "growth faltering" were $4.1 \pm 0.4$ (intermediate) and $3.4 \pm 0.9$ (advanced) $\mathrm{cm} /$ year [21]. Use of a single cut-off is problematic with girls aged $7.8-14.9$ years at baseline. Height increments vary with CA and tend to be skewed within age intervals [104]: Median (mean \pm SD) yearly increments (cm/year) for girls in the Zurich Longitudinal Study, for example, decreased from $6.1(6.1 \pm 0.9)$ at 
6.5 years to $5.0(5.1 \pm 1.6)$ at 9.75 years, increased to 6.3 $(6.7 \pm 1.7)$ at 11.75 years, and declined to $1.7(2.1 \pm 1.7)$ at 14.75 years of age [105]. Corresponding 25 th percentiles (cm/year) were 5.5 (6.5 years), 4.2 (9.75 years), 4.9 (11.75 years) and 0.9 (14.75 years) [105].

\subsection{Summary}

Some gymnasts show low annual height increments, but age- and maturity-associated variation, use of a single cutoff criterion, and measurement variability limit interpretations in short-term studies. Use of terminology that implies a direct causative link between gymnastics training and growth and maturity status is not warranted.

\section{Gymnastics Training Environment}

The need to specify gymnastics training beyond hours per week is obvious. Training activities include warm-up, instruction, repetitions of skills and routines and rest intervals, among others. Activities are intermittent and variable in physiological and impact demands [32]. Rest or recovery accounted for about $63 \%$ of training time among elite youth male gymnasts; work-rest ratios varied with apparatus and phase of season [31, 32]. Estimated energy cost of gymnastic activities among youth range from 3.0 (light) to 5.0 (intense) METs [28].

Given multiple factors in the environments of children and adolescents that are associated with growth and maturation $[5,73,106]$, it is imperative that the culture and environment of training and competition in artistic gymnastics be critically evaluated. Growth and maturation do not occur in a social vacuum. The psychosocial environment of the sport may tacitly or explicitly foster limited weight gain when accretion of mass is expected with normal growth. Training and competitive environments are controlled by adults-coaches, officials, administrators and complicit parents. Optimal training and success are the goals, but coaching styles, demands and expectations vary. The sport is extremely selective; many gymnasts are excluded voluntarily or involuntarily.

Adolescent female artistic gymnasts, especially those who are elite or are approaching elite status, face challenges related to body size [14]. Changes in size, proportions and composition associated with growth and maturation may in turn influence performance. For example, gymnastic manoeuvres involving rotation appear to favour gymnasts who are shorter and have a lower centre of gravity [107]. The physical and functional characteristics of gymnasts hold important social stimulus value, ultimately influencing perceptions of and reactions to coaches.
For example, high-school female gymnasts (median age 15 years) who were taller and heavier and had an elevated BMI compared with gymnastics peers perceived their coaches as less reinforcing, encouraging and instructive, and had less positive and supportive interactions with coaches [108]. BMI was also inversely related to psychological well-being, while the interaction of height (shorter) and coping strategies (maladaptive) was a predictor of psychological distress [109]. Although limited to high school in contrast to more elite female gymnasts, the results highlight the psychosocial implications of body size.

Superimposed on the demands of normal growth and maturation, gymnastics coaches often have concerns about the size, mass and pubertal maturation of young female gymnasts. This was apparent in the semi-popular book, Little Girls in Pretty Boxes: The Making and Breaking of Elite Gymnasts and Figure Skaters [91], which highlighted interactions among harsh coaching methods, high levels of stress, disordered eating and manipulation in the young athletes in both sports. Indeed, some young female gymnasts were considered at increased risk for disordered eating behaviours $[92,93]$, while a small number of elite Swiss adolescent female gymnasts (three of 27) were considered at risk for "manifest mental disorder over time" [110]. The influence of an environment of dependency on and control by coaches on young gymnasts needs systematic evaluation.

The environment of competitions may also be a source of stress regarding size and maturation for female gymnasts. Analysis of performance scores from the 1987 WC in Rotterdam indicated moderate negative relationships between individual skinfold thicknesses and endomorphy (sum of three skinfold thicknesses adjusted for height) and scores on individual events and the total score [111]. The elite female artistic gymnasts were neither fat nor endomorphic [112]. Moreover, within each $\mathrm{CA}$ group from 14 through 16 years at the $1987 \mathrm{WC}$, pre-menarcheal gymnasts received, on average, higher total scores than post-menarcheal gymnasts [61]. The trends suggest two potentially relevant and important questions. First, do judges prefer a pre-menarcheal body form among artistic gymnasts? Second, are pre-menarcheal gymnasts better performers than post-menarcheal gymnasts of the same CA?

\subsection{Summary}

Data dealing with culture and environment of artistic gymnastics are lacking. The popular literature for female gymnasts and limited research suggest a need for critical evaluation of the environment of the sport. 


\section{Familial Factors}

Familial investments and expectations in gymnastics vary and likely influence family dynamics. Environmental cues associated with living or rearing conditions have long been recognized as capable of influencing growth and maturation $[5,73,106]$. Familial correlation in height and age at menarche is obvious. Children from larger families tend to be, on average, shorter and attain menarche later than children from smaller families [5, 74]. Estimated effects of family size on menarche, controlling for birth order, were 0.15 to 0.22 and 0.08 to 0.19 years per additional sibling in athletes and non-athletes, respectively [5, 113]. Athletes tend to come from larger families [114, 115]. Mean family sizes of 11 male and 15 female gymnasts at the 1976 Montreal $\mathrm{OG}$ were $3.6 \pm 2.2$ and $3.8 \pm 2.5$ children, respectively [115]. One male and no females were from a single-child family. More recent data are lacking.

Family environments are also related to menarche. High-quality, warm environments were associated with later menarche, while socially adverse environments were associated with earlier menarche [106, 116]. The trend for talented young gymnasts to move from home to sport schools and training centres is an additional factor that needs study in this regard $[117,118]$.

\section{Conclusions}

Data dealing with growth and maturation of artistic gymnasts are more available for females than males. Moreover, demands of the sport and intensity of training differ by sex. Artistic gymnastics for males includes six events compared to four events for females. Training loads of males are thus attenuated (same training hours) over more movement patterns, while events for females have undergone considerable convergence in the past 10 years or so. Tumbling, vaulting and the beam incorporate very similar skills so that training involves increased repetitions with fewer movement patterns.

Youth who persist in artistic gymnastics are highly select and tend to be shorter. Secondary sex characteristics, $\mathrm{SA}$ and age at PHV indicate later maturation, but values overlap normal variability observed in longitudinal studies, specifically studies of short- and late-maturing adolescents who are not athletes.

Allowing for limitations of available data, the following conclusions are warranted:

(1) Adult height or near adult height of female and male artistic gymnasts is not compromised by intensive gymnastics training at a young age or during the pubertal growth spurt.
(2) Gymnastics training does not attenuate growth of upper (sitting height) or lower (legs) body segment lengths.

(3) Gymnastics training does not appear to attenuate pubertal growth and maturation, including SA, secondary sex characteristics and age at menarche, and rate of growth and timing and tempo of the growth spurt. Data for other aspects of the growth spurt in gymnasts are lacking (age and height at onset, growth in height from onset to PHV and from PHV to young adulthood). Some gymnasts have height increments below the normal range for age and/or maturity status, but it is problematic to interpret these relatively shortterm studies using a single height velocity cut-off allowing for measurement variability. Growth rates of individual gymnasts should be monitored to ensure that variations of potential clinical importance can be noted and referred for appropriate medical attention.

(4) Presently available data are inadequate to address the issue of intensive gymnastics training and alterations within the endocrine system.

(5) Though shorter and lighter than average, gymnasts have appropriate weight-for-height.

Available data indicate that artistic gymnasts of both sexes are shorter and lighter than CA-matched peers; have appropriate weight-for-height and body proportions; do not appear to have compromised pubertal maturation; and do not have compromised adult stature. Male gymnasts have been studied less extensively than females so that additional data are required before gender-specific statements can be made.

Given the individuality of physical growth and biological maturation and the variety of factors known to influence these processes, it is difficult to specify effects attributable to systematic training in artistic gymnastics. The issue is confounded by limitations of the available data for gymnasts and the selectivity of the sport (differential dropout rate). The majority of studies are cross sectional, have small sample sizes, involve athletes with variable levels of training and skill, and do not include variables known to influence growth and maturation. The few longitudinal studies start at relatively late CAs so that it is difficult to satisfactorily capture important aspects of the adolescent growth spurt (age and size at take-off, age and size at PHV, and so on).

Comprehensive longitudinal studies are needed to satisfactorily address questions related to potential effects of training on the physical growth and biological maturation of gymnasts of both sexes. Studies should start prior to commencement of formal gymnastics training (about 4-6 years of age) and should include comparison groups of similar age who are not involved in training. Since 
gymnasts tend to demonstrate patterns of growth characteristic of short-, late-maturing youth with short parents, it is important that comparison groups also demonstrate these characteristics. An indicator of biological maturation that spans early childhood through adolescence is essential, as is a measure of pubertal maturation that incorporates systematic assays of hormonal changes. Finally, studies should also include measures of other variables known to effect growth and maturation, such as dietary intake, family size and related characteristics and, of course, indicators of training time, intensity and environment.

There is also a need to recognize the individuality of responses to training and to specify details of training beyond hours per week. This would permit better understanding of the energetic, physiological and biomechanical demands and the technical complexities of training and competition in artistic gymnastics for girls and boys. This should be done in the context of the growth and biological maturation of the young athletes, which should be monitored longitudinally from childhood through adolescence into young adulthood. Given the national and international attention to gymnastics, the overall environment of the sport needs systematic evaluation. Such a comprehensive approach would provide a broader framework within which to address the basic questions and related issues considered in this report.

Acknowledgments The authors would like to acknowledge and thank the Fédération Internationale de Gymnastique (FIG) for funding this conference and for giving the participants complete and free control over the content and manner of discussions. They would also like to thank the President, Prof. Bruno Grandi, and the Secretary General, Mr. André Gueisbuhler, for opening and closing the colloquium and to the 1st Vice President, Dr. Michel Léglise, for attending the first day. No funds were provided for the preparation of the paper and none of the authors have any conflicts of interest directly related to the content of this paper.

Open Access This article is distributed under the terms of the Creative Commons Attribution Noncommercial License which permits any noncommercial use, distribution, and reproduction in any medium, provided the original author(s) and the source are credited.

\section{References}

1. Malina RM. Physical growth and biological maturation of young athletes. Exerc Sport Sci Rev. 1994;22:389-433.

2. Malina RM. Growth and maturation of elite female gymnasts: is training a factor? In: Zemel B, Eveleth PB, Johnston FE, editors. Human growth in context. London: Smith-Gordon; 1999. p. 291-301.

3. Beunen GP, Malina RM, Thomis M. Physical growth and maturation of female gymnasts. In: Johnston FE, Zemel B, Eveleth PB, editors. Human growth in context. London: SmithGordon; 1999. p. 281-9.

4. Claessens AL. Elite female gymnasts: a kinanthropometric overview. In: Johnston FE, Zemel B, Eveleth PB, editors.
Human growth in context. London: Smith-Gordon; 1999. p. $273-80$.

5. Malina RM, Bouchard C, Bar-Or O. Growth, maturation, and physical activity. 2nd ed. Champaign: Human Kinetics; 2004.

6. Claessens AL. Growth and maturity status of elite female gymnasts: state of the art. In: Proceedings of the 10th sport kinetics conference (lecture), Belgrade; 2007.

7. Official Website of the Beijing 2008 Olympic Games. Female artistic gymnasts; 2008. http://en.beijing2008.cn/ (Accessed 26 Feb 2009).

8. Ziemilska A. Wpływ Intensywnego Treningu Gimnastycznego na Rozwój Somatyczny i Dojrzewanie Dzieci. Warsaw: Akademia Wychowania Fizycznego; 1981.

9. Ziemilska A. Effects of intensive gymnastics training on growth and maturation of children. Biol Sport. 1985;8:279-94.

10. Jost-Relyveld A, Sempé M. Analyse de la croissance et de la maturation squelettique de 80 jeunes gymnastes internationaux. Pediatrie. 1982;37:247-62.

11. Jahreis G, Kauf E, Frohner G, et al. Influence of intensive exercise on insulin-like growth factor I, thyroid and steroid hormones in female gymnasts. Growth Regul. 1991;1:95-9.

12. Theintz GE, Howald H, Weiss U, et al. Evidence for a reduction of growth potential in adolescent female gymnasts. J Pediatr. 1993;122:306-13.

13. Lindholm C, Hagenfeldt K, Ringertz B-M. Pubertal development in elite juvenile gymnasts: effects of physical training. Acta Obstet Gynecol Scand. 1994;73:269-73.

14. Tofler IR, Stryer BK, Micheli LJ, Herman LR. Physical and emotional problems of elite female gymnasts. N Eng J Med. 1996;335:281-3.

15. Georgopolous NA, Markou KB, Theodoropoulou A, et al. Growth, pubertal development, skeletal maturation and bone mass acquisition in athletes. Hormones. 2004;3:233-43.

16. Georgopolous NA, Theodoropoulou A, Leglise M, et al. Growth and skeletal maturation in male and female artistic gymnasts. J Clin Endocrinol Metab. 2004;89:4377-82.

17. Markou KB, Mylonas P, Theodoropoulou A, et al. The influence of intensive physical exercise on bone acquisition in adolescent elite female and male artistic gymnasts. J Clin Endocrinol Metab. 2004;89:4383-7.

18. Theodoropoulou A, Markou KB, Vagenakis GA, et al. Delayed but normally progressed puberty is more pronounced in artistic compared with rhythmic elite gymnasts due to the intensity of training. J Clin Endocrinol Metab. 2005;90:6022-7.

19. Caine D, Lewis R, O'Connor P, et al. Does gymnastics training inhibit growth of females? Clin J Sports Med. 2001;11:260-70.

20. Caine D, Bass S, Daly R. Does elite competition inhibit growth and delay maturation in some gymnasts? Quite possibly. Pediatr Exerc Sci. 2003;15:360-72.

21. Daly RM, Caine D, Bass SL, et al. Growth of highly versus moderately trained competitive female artistic gymnasts. Med Sci Sports Exerc. 2005;37:1053-60.

22. Baxter-Jones ADG, Maffulli N, Mirwald RL. Does elite competition inhibit growth and delay maturation in some gymnasts? Probably not. Pediatr Exerc Sci. 2003;15:373-82.

23. Georgopoulos NA, Markou KB, Theodoropoulou A, et al. Growth retardation in artistic compared with rhythmic elite female gymnasts. J Clin Endocrinol Metab. 2002;87:3169-73.

24. Hartley GL. A comparative view of talent selection for sport in two socialist states - the USSR and the DDR-with particular reference to gymnastics. In: The growing child in competitive sport: proceedings of the BANC International Congress; 1987, Cardiff: The National Coaching Foundation; 1988. p. 50-6.

25. Baxter-Jones ADG, Helms PJ. Effects of training at a young age: a review of the Training of Young Athletes (TOYA) study. Pediatr Exerc Sci. 1996;8:310-27. 
26. Rowley S. Training of Young Athletes study: TOYA and intensive training. London: The Sports Council; 1993.

27. USA Gymnastics. Coaching elite athletes, no date. http://www. usa-gymnastics.org/pages/women/pages/coaching_elite_athletes. html (Accessed 3 Feb 2011).

28. Ridley K, Ainsworth BE, Olds S. Development of a compendium of energy expenditures for youth. Int J Behav Nutr Phys Act. 2008;5:45-52.

29. Ridley K, Olds TS. Assigning energy costs to activities in children: a review and synthesis. Med Sci Sports Exerc. 2008;40:1439-46.

30. Laing EM, Wilson AR, Modlesky CM, et al. Initial years of recreational artistic gymnastics training improves lumbar spine bone mineral accrual in 4- to 8-year-old females. J Bone Miner Res. 2005;20:509-19.

31. Daly RM, Rich PA, Klein R. Hormonal responses to physical training in high-level peripubertal male gymnasts. Eur J Appl Physiol. 1998;79:74-81.

32. Daly RM, Rich PA, Klein R, et al. Effects of high-impact exercise on ultrasonic and biochemical indices of skeletal status: a prospective study in young male gymnasts. J Bone Miner Res. 1999;14:1222-30.

33. Caine D, Caine D, Cochrane B, et al. An epidemiologic investigation of injuries affecting young competitive female gymnasts. Am J Sports Med. 1989;17:811-20.

34. Bouchard C, Malina RM, Perusse L. Genetics of fitness and physical performance. Champaign: Human Kinetics; 1997.

35. O'Kane JW, Levy MA, Pietila K, et al. Survey of injuries in Seattle area level 4-10 club gymnasts. Clin J Sports Med. 2011;21:486-92.

36. Erlandson MC, Kontulainen SA, Chilibeck PD, et al. Bone mineral accrual in 4- to 10-year-old precompetitive, recreational gymnasts: a 4-year longitudinal study. J Bone Miner Res. 2011;26:1313-20.

37. Peltenburg AL, Erich WBM, Bernink MJE, et al. Biological maturation, body composition, and growth of female gymnasts and control groups of schoolgirls and girl swimmers, aged 8 to 14 years: a cross-sectional survey of 1064 girls. Int J Sports Med. 1984;5:36-42.

38. Theintz GE, Howald H, Allemann Y, et al. Growth and pubertal development of young female gymnasts and swimmers: a correlation with parental data. Int J Sports Med. 1989;10:87-91.

39. Peltenburg AL, Erich WBM, Zonderland ML, et al. A retrospective growth study of female gymnasts and girl swimmers. Int J Sports Med. 1984;5:262-7.

40. Damsgaard R, Bencke J, Matthiesen G, et al. Is prepubertal growth adversely affected by sport? Med Sci Sports Exerc. 2000;32:1698-703.

41. Keller E, Fröhner G. Growth and development of boys with intensive training in gymnastics during puberty. In: Laron $\mathrm{Z}$, Rogol AD, editors. Hormones and sport. New York: Raven Press; 1989. p. 11-20.

42. Erlandson MC, Sherar LB, Mirwald RL, et al. Growth and maturation of adolescent female gymnasts, swimmers, and tennis players. Med Sci Sports Exerc. 2008;40:34-42.

43. Baxter-Jones ADG, Helms P, Maffulli N, et al. Growth and development of male gymnasts, swimmers, soccer and tennis players: a longitudinal study. Ann Hum Biol. 1995;22:381-94.

44. Tönz O, Stronski SM, Gmeiner CYK. Wachstum und Pubertät bei 7- bis 16 jahrigen Kunstturneirinnen: eine prospektive Studie. Schweiz med Wschr. 1990;120:10-20.

45. USA Gymnastics. Do you know your stats? Indianapolis: USA Gymnastics; 2009. p. 32-4.

46. Claessens AL, Lefevre J. Morphological and performance characteristics as drop-out indicators in female gymnasts. J Sports Med Phys Fitness. 1998;38:305-9.
47. Council of Europe, Committee for the Development of Sport. EUROFIT: handbook for the EUROFIT tests of physical fitness. Rome: Council of Europe; 1998.

48. Lindner KJ, Caine DJ, Johns DP. Withdrawal predictors among physical and performance characteristics of female competitive gymnasts. J Sports Sci. 1991;9:259-72.

49. Roche AF, Davila GH. Late adolescent growth in stature. Pediatrics. 1972;50:874-80.

50. Khamis HJ, Roche AF. Growth outcome of "normal" short children who are retarded in skeletal maturation. J Pediatr Endocrinol Metab. 1995;8:85-96.

51. Kozieł SM. Combined effects of the tempo of maturation and midparent height on the shape of individual growth curves. Am J Hum Biol. 1997;9:555-63.

52. Rekers-Mombarg LTM, Cole TJ, Massa GG, et al. Longitudinal analysis of growth in children with idiopathic short stature. Ann Hum Biol. 1997;24:569-83.

53. Brämswig JH, Fasse M, Holthoff M-L, et al. Adult height in boys and girls with untreated short stature and constitutional delay of growth and puberty: accuracy of five different methods of height prediction. J Pediatr. 1990;117:886-91.

54. Jancarik A, Salmela JH. Longitudinal changes in physical, organic and perceptual factors in Canadian male gymnasts. In: Petiot B, Salmela JH, Hoshizaki TB, editors. World identification systems for gymnastic talent. Montreal: Sport Psyche Editions; 1987. p. 151-9.

55. Bielicki T, Szklarska A, Welon Z, et al. Nierówności społeczne w Polsce: antropologiczne badania poborowyczh w trzydziestoleciu 1965-1995. Monographs of the Institute of Anthropology, No 16. Wroclaw: Polish Academy of Sciences; 1997.

56. Bielicki T, Malina RM, Waliszko H. Monitoring the dynamics of social stratification: statural variation among Polish conscripts in 1976 and 1986. Am J Hum Biol. 1992;4:345-52.

57. Buckler JMH, Brodie DA. Growth and maturity characteristics of schoolboy gymnasts. Ann Hum Biol. 1977;4:455-63.

58. Thomis M, Claessens AL, Lefevre J, et al. Adolescent growth spurts in female gymnasts. J Pediatr. 2005;146:239-44.

59. Caldarone G, Leglise M, Giampietro M, et al. Anthropometric measurements, body composition, biological maturation and growth predictions in young female gymnasts of high agonistic level. J Sports Med. 1986;26:263-73.

60. Caldarone G, Leglise M, Giampietro M, et al. Anthropometric measurements, body composition, biological maturation and growth predictions in young male gymnasts of high agonistic level. J Sports Med. 1986;26:406-15.

61. Claessens AL, Lefevre J, Beunen GP, Malina RM. Maturityassociated variation in the body size and proportions of elite female gymnasts 14-17 years of age. Eur J Pediatr. 2006;165:186-92.

62. Bass S, Bradney M, Pearce G, et al. Short stature and delayed puberty in gymnasts: influence of selection bias on leg length and the duration of training on trunk length. J Pediatr. 2000;136:149-55.

63. Daly RM, Rich PA, Klein R, et al. Short stature in competitive prepubertal and early pubertal male gymnasts: the results of selection bias or intense training. J Pediatr. 2000;137:510-6.

64. Roche AF, Malina RM. Manual of physical status and performance in childhood, vol. 1. Physical status. New York: Plenum; 1983.

65. Malina RM. Skeletal age and age verification in youth sport. Sports Med. 2011;41:925-47.

66. Bass S, Pearce G, Bradney M, et al. Exercise before puberty may confer residual benefits in bone density in adulthood: studies in active prepubertal and retired female gymnasts. J Bone Miner Res. 1998;13:500-7.

67. Duvallet A, Leglise M, Auberge T, et al. Étude radiologique des lésions osseuses du poignet du sportif : a propos de 98 
radiographies du poignet et de la main gauche chez le gymnaste junior Européen de haut niveau. Cinésiologie. 1983;22:157-62.

68. Rich PA, Fulton A, Ashton J, et al. Training and testosterone in elite young gymnasts. Aust J Sci Med Sport. 1992;24:68-72.

69. Weimann E, Witzel C, Schwidergall S, et al. Peripubertal perturbations in elite gymnasts caused by sport specific training regimes and inadequate nutritional intake. Int $\mathbf{J}$ Sports Med. 2000;21:210-5.

70. Zemel BS, Johnston FE. Applications of the Preece-Baines growth model to cross-sectional data: problems of validity and interpretation. Am J Hum Biol. 1994;6:563-70.

71. Mirwald RL, Baxter-Jones ADG, Bailey DA, et al. An assessment of maturity from anthropometric measurements. Med Sci Sports Exerc. 2002;24:689-94.

72. Nurmi-Lawton JA, Baxter-Jones AD, Mirwald RL, et al. Evidence of sustained skeletal benefits from impact-loading exercise in young females: a 3-year longitudinal study. J Bone Miner Res. 2004;19:314-22.

73. Irurtia Amigo A, Busquets Faciabén A, Evrard MM, et al. Height, weight, somatotype and body composition in elite Spanish gymnasts from childhood to adulthood. Apunts Med Esport. 2009;161:18-28.

74. Tanner JM. Growth at adolescence. 2nd ed. Oxford: Blackwell Scientific Publications; 1962.

75. Geithner CA, Woynarowska B, Malina RM. The adolescent spurt and sexual maturation in girls active and not active in sport. Ann Hum Biol. 1998;25:415-23.

76. Gurd B, Klentrou P. Physical and pubertal development in young male gymnasts. J Appl Physiol. 2003;95:1011-5.

77. Malina RM, Ryan RC, Bonci CM. Age at menarche in athletes and their mothers and sisters. Ann Hum Biol. 1994;21:417-22.

78. Baxter-Jones ADG, Helms P, Baines-Preece J, et al. Menarche in intensively trained gymnasts, swimmers and tennis players. Ann Hum Biol. 1994;21:407-15.

79. Theintz G. Endocrine adaptation to intensive physical training during growth. Clin Endocrinol. 1994;41:267-72.

80. Loucks AB. The response of luteinizing hormone pulsatility to 5 days of low energy availability disappears by 14 years of gynecological age. J Clin Endocrinol Metab. 2006;91:3158-64.

81. Loucks AB, Thuma JR. Luteinizing hormone pulsatility is disrupted at a threshold of energy availability in regularly menstruating women. J Clin Endocrinol Metab. 2003;88:297-311.

82. Shackleton C. Clinical steroid mass spectrometry: a 45-year history culminating in HPLA-MS/MS becoming an essential tool for patient diagnosis. J Steroid Biochem Mol Biol. 2010;121:481-90.

83. Stanczyk FZ, Clarke NJ. Advantages and challenges of mass spectrometry assays for steroid hormones. J Steroid Biochem Mol Biol. 2010;121:491-5.

84. Peltenburg AL, Erich WBM, Thijssen JJH, et al. Sex hormone profiles of premenarcheal athletes. Eur J Appl Physiol. 1984;52:385-92.

85. De Ridder CM, Zonderland ML, Thijssen JJH, et al. The onset of puberty and the availability of sex steroids in female gymnasts. Am J Hum Biol. 1993;5:251-7.

86. Soliman AT, Hassan AEHI, Aref MK, et al. Serum insulin-like growth factors (IGF) I and II concentrations and GH and insulin responses to arginine in children with protein-energy malnutrition before and after nutritional rehabilitation. Pediatr Res. 1986;20:1122-30.

87. Weimann E. Gender-related differences in elite gymnasts: the female athlete triad. J Appl Physiol. 2002;92:2146-52.

88. Press A. Old too soon, wise too late? Newsweek (10 Aug), 1992. p. 22-4. http://www.thedailybeast.com/newsweek/1992/08/09/oldtoo-soon-wise-too-late.html (Accessed 4 Apr 2013).
89. Prieser U. Faszinierende Artistik oder "Kindersmißbrauch" wie jung dürfen Kunstturnerinnen sein? Die Hochleistungskinder. Die Zeit. 1992; Dec 11; p. 22.

90. Becker D, Brown B. USA gymnastics, IOC try to tackle eating disorders. USA Today. 1995;21:10C.

91. Ryan J. Little girls in pretty boxes: the making and breaking of elite gymnastics and figure skaters. New York: Doubleday; 1995.

92. O'Connor PJ, Lewis RD, Boyd A. Health concerns of artistic women gymnasts. Sports Med. 1996;21:321-5.

93. Schwidergall S, Weimann E, Witzel C, et al. Ernährungsverhalten bei weiblichen und männlichen Hochleistungsturnern. Wien Med Wochenschr. 1998;148:243-4.

94. Davies PSW, Feng J-Y, Crisp JA, et al. Total energy expenditure and physical activity in young Chinese gymnasts. Pediatr Exerc Sci. 1997;9:243-52.

95. Lindholm C, Hagenfeldt K, Hagman U. A nutrition study of juvenile elite gymnasts. Acta Paediatr. 1995;84:273-7.

96. Deutz RC, Bernadot D, Martin DE, et al. Relationship between energy deficits and body composition in elite female gymnasts and runners. Med Sci Sports Exerc. 2000;32:659-68.

97. Cole TJ, Flegal KM, Nicholls D, et al. Body mass index cut offs to define thinness in children and adolescents: international survey. Br Med J. 2007;335:194-201.

98. Freedman DS, Wang J, Maynard LM, et al. Relation of BMI to fat and far-free mass among children and adolescents. Int J Obes. 2005;29:1-8.

99. Associated Press. Earlier state media report listed gymnast He's age as 13; 2008. http://sports.espn.go.com/oly/summer08/ gymnastics/news/story?id=3534544 (Accessed 14 Aug 2008).

100. Associated Press. Chinese gymnasts cleared, but two from 2000 games still eyed; 2008. http://sports.espn.go.com/oly/ gymnastics/news/story?id=3619325 (Accessed 1 Oct 2008).

101. Macur J. A visit to the athletes' village to see the (perhaps underage) Chinese gymnasts. New York Times; 2008. http://beijing2008.blogs.nytimes.com/2008/08/03/a-visit-to-theathletes-village-to-see-the-perhaps-underage-chinese-gymnasts/ ?scp=1\&sq=Macur\%20A\%20visit $\% 20$ to $\% 20$ the $\% 20$ athletes $\%$ 20village $\% 203 \% 20 \% 22$ August $\% 202008 \% 22 \&$ st $=$ cse (Accessed 12 Aug 2008).

102. Roche AF, Himes JH. Incremental growth charts. Am J Clin Nutr. 1980;33:2041-52.

103. Lindsay R, Feldkamp M, Harris D, et al. Utah Growth Study: growth standards and the prevalence of growth hormone deficiency. J Pediatr. 1994;125:29-35.

104. Baumgartner RN, Roche AF, Himes JH. Incremental growth tables: supplementary to previously published charts. Am J Clin Nutr. 1986;43:711-22.

105. Prader A, Largo RH, Molinari L, et al. Physical growth of Swiss children from birth to 20 years of age: First Zurich Longitudinal Study of Growth and Development. Helvet Paediatr Acta. 1989;Suppl 52:1-125.

106. Ellis BJ. Timing of pubertal maturation in girls: an integrated life history approach. Psychol Bull. 2004;130:920-58.

107. Ackland T, Elliott B, Richards R. Growth in body size affects rotational performance in women's gymnastics. Sports Biomech. 2003;2:163-76.

108. Cumming SP, Eisenmann JC, Smoll FL, et al. Body size and perceptions of coaching behaviors by adolescent female athletes. Psychol Sport Exerc. 2005;6:693-705.

109. Cumming SP, Smith RE, Grossbard JR, et al. Body size, coping strategies, and mental health in adolescent female athletes. Int $\mathbf{J}$ Sports Sci Coach. 2012;7:515-26.

110. Theintz G, Ladame F, Kehre E, et al. Prospective study of psychological development of adolescent female athletes: initial assessment. J Adolesc Health. 1994;15:258-62. 
111. Claessens AL, Lefevre J, Beunen G, Malina RM. The contribution of anthropometric characteristics to performance scores in elite female gymnasts. J Sports Med Phys Fitness. 1999;39:355-60.

112. Claessens AL, Veer FM, Stijnen V, et al. Anthropometric characteristics of outstanding male and female gymnasts. J Sports Sci. 1991;9:53-74.

113. Malina RM, Katzmarzyk PT, Bonci CM, et al. Family size and age at menarche in athletes. Med Sci Sports Exerc. 1997;29:99-106.

114. De Garay AL, Levine L, Carter JEL. Genetic and anthropological studies of Olympic athletes. New York: Academic Press; 1974.

115. Malina RM, Bouchard C, Shoup RF, et al. Age, family size and birth order in Montreal Olympic athletes. In: Carter JEL, editor. Physical structure of Olympic athletes: part I. The Montreal Olympic Games Anthropological Project. Basel: Karger; 1982. p. 13-24.

116. Ellis BJ, Essex MJ. Family environments, adrenarche, and sexual maturation: a longitudinal test of a life history model. Child Dev. 2007;78:1799-817.

117. Kantrowitz B, Starr M, Wilson DJ. Living with training. Newsweek; 1992. p. 24-5. http://www.thedailybeast.com/news week/1992/08/10/living-with-training.html (Accessed 4 Apr 2013).

118. Beech J. The price of gold. Time Magazine Asia; 2004. http://www.time.com/time/magazine/article/0,9171,678686-3,00. html (Accessed 22 Apr 2013).
119. Prokopec M. Die Bedeutung der Körperhöhe der Eltern für die richtige Bewertung des Kinderwachstums. Arztl. Jugendkd. 1977;68:70-6.

120. Claessens AL, Malina RM, Lefevre J, et al. Growth and menarcheal status of elite female gymnasts. Med Sci Sports Exerc. 1992;24:755-63.

121. Kirchner EM, Lewis RD, O'Connor PJ. Bone mineral density and dietary intake of female college gymnasts. Med Sci Sports Exerc. 1995;27:543-9.

122. Pollock NK, Laing EM, Modlesky CM, et al. Former college artistic gymnasts maintain higher BMD: a nine-year follow-up. Osteoporos Int. 2006;17:1691-7.

123. Faria IE, Faria EW. Relationship of the anthropometric and physical characteristics of male junior gymnasts to performance. J Sports Med Phys Fitness. 1989;29:369-78.

124. Österback LL, Viitasalo J. Growth selection of young boys participating in different sports. In: Rutenfranz J, Mocellin R, Klimt F, editors. Champaign: Human Kinetics; 1986. p. 373-80.

125. Beunen G, Claessens A, Wellens R, et al. Biological maturity status of Belgian athletes. In: Proceedings of the international congress on child and sport. Urbino: School of Sport of the Italian National Olympic Committee; 1984.

126. Malina RM, Bouchard C, Shoup RF, et al. Growth and maturity status of Montreal Olympic athletes less than 18 years of age. Med Sport. 1982;16:117-27.

127. World Health Organization. Physical status: the use and interpretation of anthropometry. Geneva: World Health Organization, Technical Report Series, No. 854; 1995. 